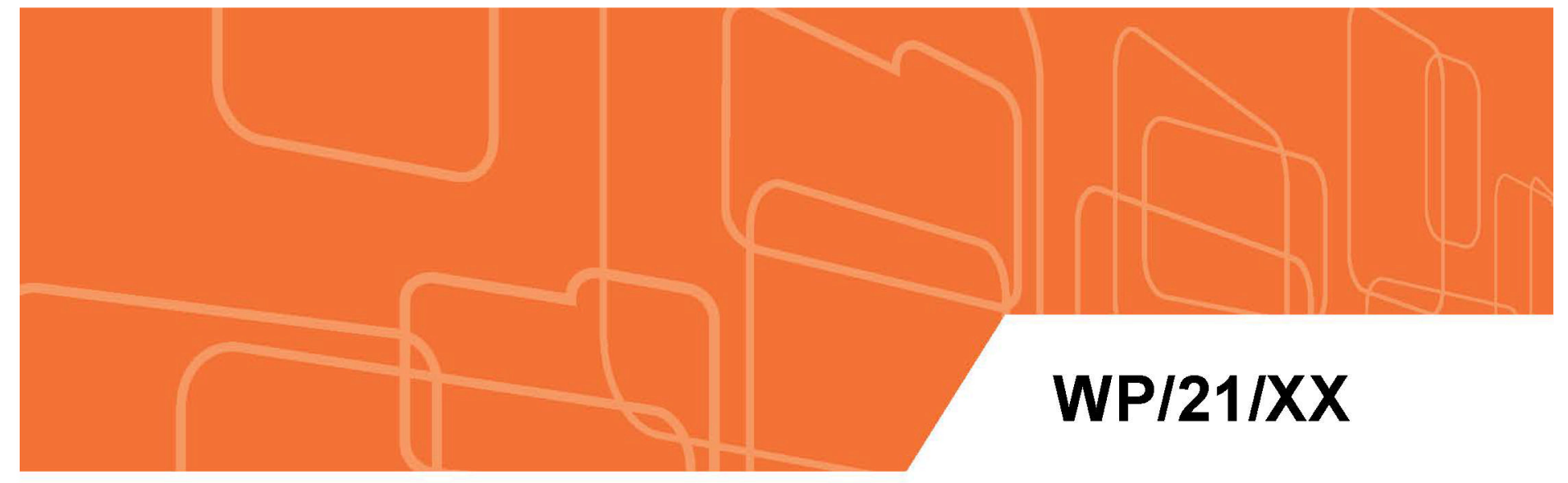

IMF Working Paper

\title{
The Political Economy of Inclusive Growth: A Review
}

by Barbara Dutzler, Simon Johnson, and Priscilla Muthoora

IMF Working Papers describe research in progress by the author(s) and are published to elicit comments and to encourage debate. The views expressed in IMF Working Papers are those of the author(s) and do not necessarily represent the views of the IMF, its Executive Board, or IMF management. 


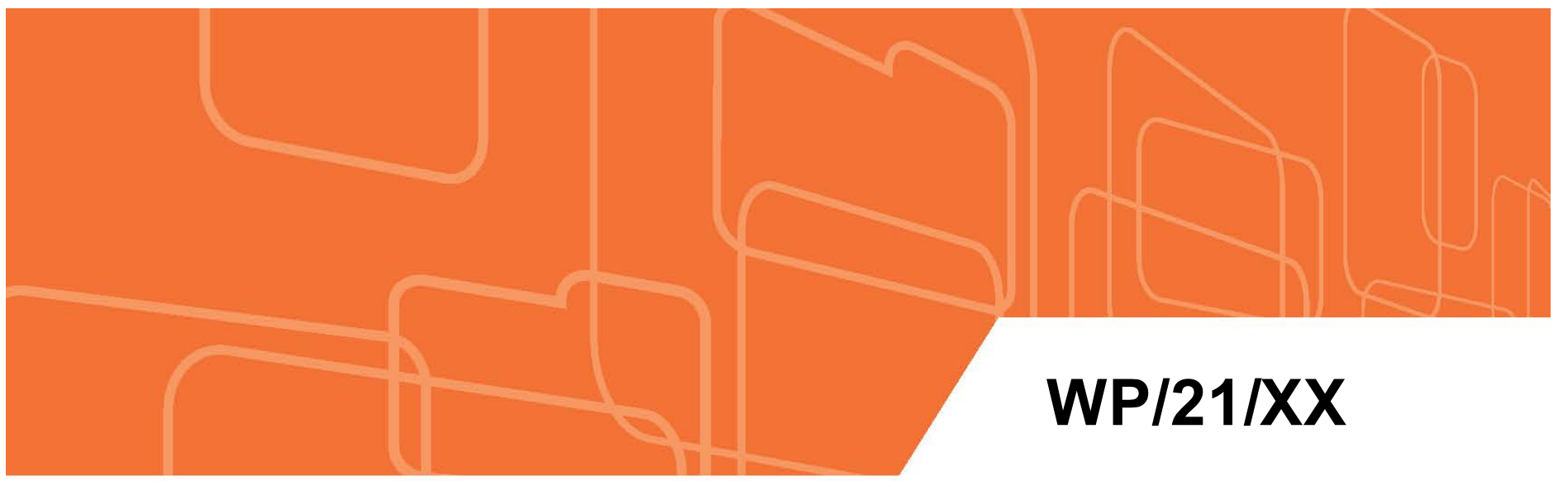

\section{IMF Working Paper}

\section{The Political Economy of Inclusive Growth: A Review}

by Barbara Dutzler, Simon Johnson, and Priscilla Muthoora

IMF Working Papers describe research in progress by the author(s) and are published to elicit comments and to encourage debate. The views expressed in IMF Working Papers are those of the author(s) and do not necessarily represent the views of the IMF, its Executive Board, or IMF management. 


\title{
IMF Working Paper
}

Institute for Capacity Development

The Political Economy of Inclusive Growth: A Review

Prepared by Barbara Dutzler, Simon Johnson, and Priscilla Muthoora ${ }^{1}$

Authorized for distribution by Valerie Cerra

March 2021

\section{IMF Working Papers describe research in progress by the author(s) and are} published to elicit comments and to encourage debate. The views expressed in IMF Working Papers are those of the author(s) and do not necessarily represent the views of the IMF, its Executive Board, or IMF management.

\begin{abstract}
In this paper, we review the role of the political economy in inclusive growth. We find that political economy forces on the demand and supply side have weakened redistribution over time and contributed to a new wave of populism. We document growing support for a rethink of the social contract to make growth more inclusive and discuss some of its broad elements.
\end{abstract}

JEL Classification Numbers: D72, D31, O11

Keywords: Political Economy, Inequality, Redistribution, Growth

Authors' E-Mail Addresses: bdutzler@jvi.org; sjohnson@mit.edu; pmuthoora@imf.org

\footnotetext{
${ }^{1}$ Barbara Dutzler: Joint Vienna Institute; Simon Johnson: MIT Sloa School of Management; Priscilla Muthoora: International Monetary Fund.

We thank Valerie Cerra, Moya Chin, Hamid Da voodi, Barry Eichengreen, participants in the Inclusive Growth book seminar series organized by the IMF Institute for Capacity Development, a nd colleagues from the IMF for useful comments and suggestions. We a lso thank Christina Fong, Vincent Mahler, a nd Piotr Paradowski for permission to reproduce their da ta. This is a draft of a chapter thathas been accepted by Oxford University Press for publication in the forthcoming book "How to Achieve Inclusive Growth?", edited by V. Cerra, B. Eichengreen, A. El-Ganainy, and M. Schindler, due for publication in 2021.
} 


\section{Contents}

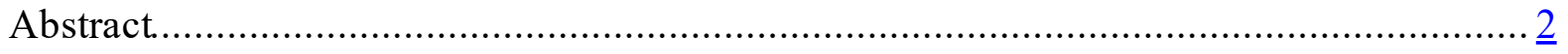

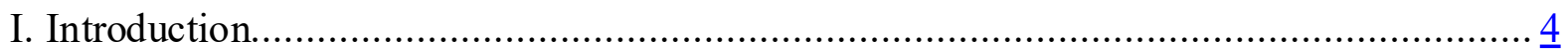

II. Demand for Redistribution: Theory and Practice ……............................................. $\underline{5}$

A. Political participation and preferences for redistribution............................................. $\underline{6}$

B. What other factors shape preferences? .............................................................

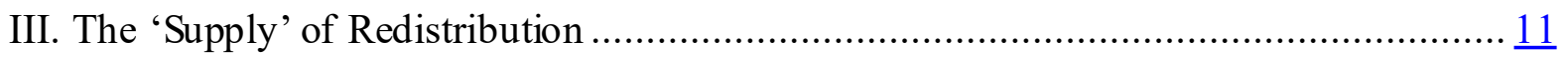

A. Setting the stage for redistribution: Welfare States............................................... $\frac{12}{12}$

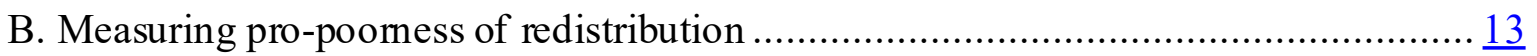

IV. Which Political Regimes Deliver More Redistribution?............................................ $\frac{17}{17}$

A. Redistribution under Proportional and Majoritarian Representation........................... $\frac{17}{17}$

B. Redistribution with Changing Political Cleavages............................................. $\frac{17}{18}$

C. Redistribution under Populism: Then and Now................................................. 18

D. Redistribution under Populism: The Outcome................................................. 20

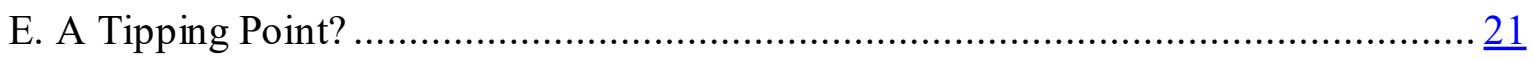

V. The 'How' and 'When' of Redistribution ............................................................. 22

A. 'Pre-distribution' versus 'Redistribution' ............................................................. 22

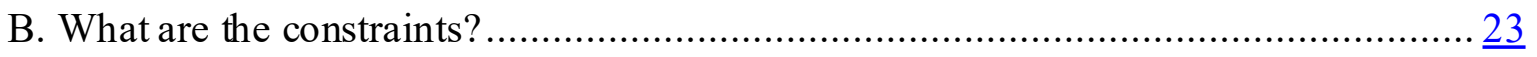

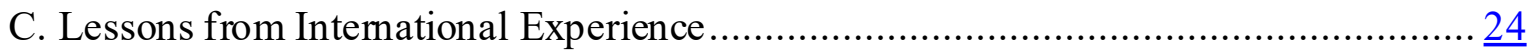

D. The COVID-19 Pandemic: A Game Changer?.................................................... $\underline{26}$

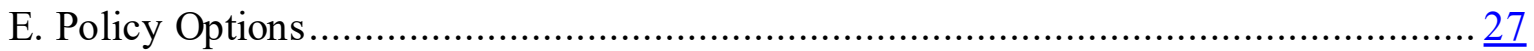

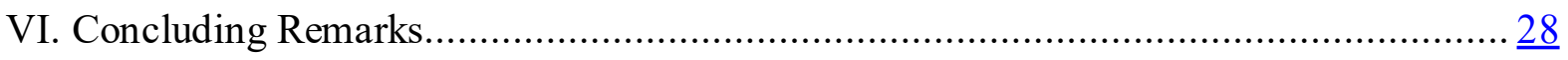

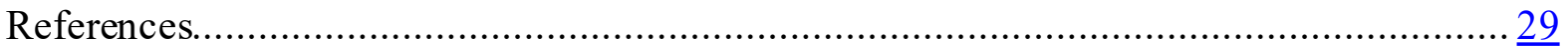

\section{Figures}

Figure 1. The Income Skew of Voter Turnout in Advanced Economies .............................. $\underline{8}$

Figure 2. Determinants of Support for or Opposition to Redistribution.............................. 10

Figure 3. Public Social spending in the OECD (Percent of GDP).................................. 14

Figure 4. Change in Income Inequality and Social Protection: 2000-2018 …..................... 15

Figure 5. Social Protection and Labor Programs (SPL)................................................ 16

Figure 6. Vote Shares in European Countries........................................................... 19

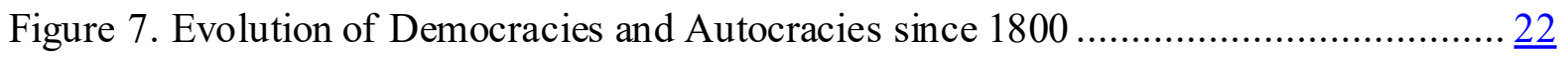




\section{INTRODUCTION}

Inclusive growth, or rather the lack of it, has become a recurring theme in political discourses. Economic growth has lifted millions of people out of poverty and led to higher living standards worldwide in the decades following World War II. Yet, there remains a sense that growth increasingly serves a privileged few while leaving many behind and that countries' national institutions and politics are not sufficiently responsive to the needs of all citizens. This perception has motivated civil protest movements, and nationalist sentiments led to greater political polarization and fueled a new wave of populism across the globe. Increasing economic inequality, the argument goes, leads to more divided societies with worse outcomes for all citizens.

In most advanced economies, income inequality is now at its highest level since the late 1970s. Among developing countries, the picture is mixed with several exceptions to the trend of increasing inequality. However, even in the countries where inequality declined, progress on other dimensions of inclusiveness has been limited. Access to education, health care, finance, and employment opportunities, for example, remain unequal (Dabla-Norris and others, 2015; IMF, 2020).

Several factors can explain the widening gap within countries between the rich and poor. They include technological changes that favor the highly-skilled; the decline of unions and thus of protection and wage bargaining power for workers; the deregulation of financial markets; the rise of market power of few superstar firms and individuals; globalization with its integrated value chains of production and relocation of production factories to low-cost developing countries; and migration on an unprecedented scale (Atkinson, 2015; Bourguignon, 2018; Sandbu, 2020).

Importantly, however, policy decisions by national governments and other economic agents play a major role in shaping the effect of these factors on economies (Atkinson, ibid). Thus, Ostry, Loungani, and Berg (2019) argue that increased inequality has been a choice, not an inevitable outcome.

In this paper, we discuss the role of the political economy - the relationships between individuals, society, markets, and the state - in inclusive growth. While interpersonal disparities related to gender, race, ethnicity, health, and education ${ }^{2}$ are critical for inclusive growth, we mainly focus on the income inequality dimension for which political economy assessments are more prevalent. A large body of scholarly research has shown that a wide set of public policies affects income inequality (and vice versa) through complex interactions with politics and political institutions, historical legacies, and endowments. ${ }^{3}$ This includes policies pertaining to labor markets, property laws, the financing of education and health

\footnotetext{
${ }^{2}$ As a re spatial disparities across these dimensions.

${ }^{3}$ See for example, the reviews in McCarthy and Pontusson(2011), Acemoglu and Robinson(2013), and Morgan and Kelly (2013).
} 
care, and the provision of public goods (implicit redistribution or 'pre-distribution' policies), on the one hand, and explicit redistribution through taxes and transfers, on the other.

We organize our review into three broad questions. First, what determines the demand for and supply of redistribution, and can these determinants explain recent trends in inequality? Second, is there a robust link between political ideologies and inequality? Third, is the trend increase in inequality self-sustaining, or is there a tipping point, especially with the COVID19 pandemic? To answer each of these questions, we draw on both theoretical and empirical studies in the political economy literature, on historical evidence, and contemporary country experiences.

Our review suggests that political economy forces, both on the demand and supply side, have weakened redistribution over time and contributed to the new wave of populism in many countries. Experience with populist experiments, however, cast doubt on the ability of this new populism to provide lasting solutions. The COVID-19 pandemic is widening economic inequalities and will test inclusive growth models. A rethink of the social contract is thus a policy imperative. This new social contract will necessarily reflect country-specific circumstances, but both the 'what' and the 'how' is important. First, in terms of content, there is growing consensus around three areas for policy interventions: investing in 'local communities, where possible; helping the creation of 'good jobs'; and improving deliberations and communications to rebuild trust in public institutions. Second, in terms of process, input matters as much as output for legitimacy. Thus, participation in decisionmaking through truly representative and democratic processes is key to ensure broad support by the population.

The remainder of this paper is organized as follows. Section II discusses the demand for redistribution, while section III focuses on the supply-side. While demand and supply are interrelated, as supply-side institutions such as the welfare state are formed by and respond to citizens' demands, for analytical purposes, they are reviewed separately. Section IV examines which political regimes deliver more redistribution. Section V discusses the when and how of redistribution, including how to transition towards new social and political arrangements when trust in the government has been eroded. Section VI concludes.

\section{DEMAND FOR REDisTRIBUtion: THEORY AND PRACTICE}

One of the most widely known results in political economy theory is that democracy leads to more redistribution and lower inequality. This result derives from the median voter model of Meltzer and Richard (1981), who showed that the decisive preference of the voter at the 
median of the income distribution, whose income is below the mean, will result in a preference for higher taxes and redistribution. ${ }^{4,5}$

History provides some support for the propositions of the model. In a study of the extension of the franchise in the West during the $19^{\text {th }}$ century, Acemoglu and Robinson (2000a) documented that broadening voting rights to greater shares of the population in England, France, Sweden, and Germany was accompanied by significant redistributive reforms financed by an increase in taxation. Social spending emerged at the same time as the expansion of political voice, enfranchising middle- and lower-income groups and women from the 1880 s to the 1960 s (Lindert, 2017). ${ }^{6}$

Recent empirical evidence also suggests that taxes are higher, and inequality is lower, on average, in democracies (Acemoglu et al., 2015). But the experience of the former communist economies (Milanovic, 1998) or South Africa in the post-apartheid era (Leibbrandt et al., 2010) shows that inequality is not necessarily self-correcting in democracies. Some scholars have documented a 'Robin Hood Paradox,' whereby countries with high levels of inequality tend to have less redistributive policies than more egalitarian ones (Lindert, 2004).

How can theory be reconciled with practice? Extensions to the basic median voter setting can alter the conclusions of the model. Benabou (2000), for example, demonstrates that there can be a non-linear relationship between the level of inequality and redistribution. This is because support for efficient redistributions, notably for social insurance, tends to be higher in more homogenous societies than in highly unequal ones. Acemoglu et al. (2015), on the other hand, explain the empirical failure of the median voter hypothesis by factors that constrain democracies. These include constitutions, conservative political parties, capital flight, or widespread tax evasion by the elite. Political inequality and other factors shaping demand for redistribution also matter in practice. We elaborate on these below.

\section{A. Political participation and preferences for redistribution}

A key assumption of the median voter model is that every person who is eligible to vote does so. Another is that every vote carries the same weight. If the political influence of individuals increases with their incomes, the rate of redistribution will be lower than in the median voter model and fall with increasing inequality (Przeworski, 2015). In terms of the median voter model, if the income of the likely voter is close to or above the mean income, this reduces

\footnotetext{
${ }^{4}$ This is the case if there are more poor people in the population than rich ones, i.e., if the respective distributions of income and wealth are skewed to the right, with thick upper tails.

${ }^{5}$ A rela ted result, in this set-up, is that greater initial inequality should lea do more redistribution given electoral competition.

${ }^{6}$ Aidt et al. (2006) find that social welfa reonly emerged relatively late and to a lesser extent, with public spending a s a percentage of GDP shifting out of defense, administration, police and judiciary first into transport, construction and communication, and subsequently into public schooling and health.
} 
demand for redistribution. Net inequality may then rise with market inequality, with only a partial correction by redistributive policies.

How relevant is this in practice? In the United States, Gilens (2009) finds that there are significant differences in income-based preferences on many social and welfare policies.

Thus, the sharp increases in incarcerated Americans and ineligible ex-felons since the 1970s and in immigration which have reduced voter turnout at the lower tail of the income distribution, may have steered policy towards the preferences of wealthier voters and away from redistribution. ${ }^{7}$ The turnout gap between the richest and poorest voter in the United States was 23.6 percentage points, versus 8.4 percentage points on average in the thirteen other OECD states for elections in the years 2001-04 (Mahler et al., 2015).

More generally, whether the poor are less likely to vote than the rich depends on additional factors, such as the government's capacity to tax and the political salience of redistribution or strategic spending by politicians, especially during election years. In developing countries, high levels of inequality can coexist with high electoral participation of the poor if electoral parties mobilize them through targeted goods, and the capacity to monitor such strategic spending by incumbents is weak. ${ }^{8}$ This can contribute to creating and maintaining bad equilibria characterized by high inequality and low state capacity.

Would a higher and more equal voter turnout, in fact, increase redistribution? Robust empirical evidence for this proposition is missing, likely because voters also care about noneconomic issues (Finseeras, 2007). In a third of the sample of fourteen OECD countries studied by Mahler et al. (2015), the turnout gap between the richest and the poorest quintile is bigger than ten percentage points. There is some evidence of a positive relationship between turnout and redistribution, but this effect is stronger for the eleven European countries in the study. The United States is an outlier, with the second-lowest voter turnout values for the bottom quintile, a significant skew of voter turnout towards high-income groups (Figure 1), and low social transfers. Two other non-European countries in the study, Australia and Canada, have low redistribution shares but, compared to the United States, lower voter inequality. A study by Fujiwara (2015) shows that the enfranchisement of the poor, through electronic voting, which improves their electoral participation, leads to greater health spending in Brazilian municipalities. Overall, these studies, although they cover a small sample of countries, provide suggestive evidence that voting rules do not imply a linear mapping of voter preferences to policy and that income is not the only factor driving preferences for redistribution.

\footnotetext{
${ }^{7}$ See, for example, Rosenthal(2004) for a discussion of the effect of 'felony disenfranchisement' and immigration on voter turnout. Further, a substantial share of eligible voters in the United States remains unregistered due to theallocation of responsibility of registering resting with the individual, not the state, unlike most of the countries a nalyzed in the sample of Mahler et al. (2015).

${ }^{8}$ Kasa ra and Suryanarayan (2014) find the rela tive turnout of the rich to be higher than the poor, where rich individuals opposeredistribution, and where governments have high ability to tax the rich. Amat and Bera mendi (2020) study the issue of strategic spending by politicians.
} 
Figure 1. The Income Skew of Voter Turnout in Advanced Economies

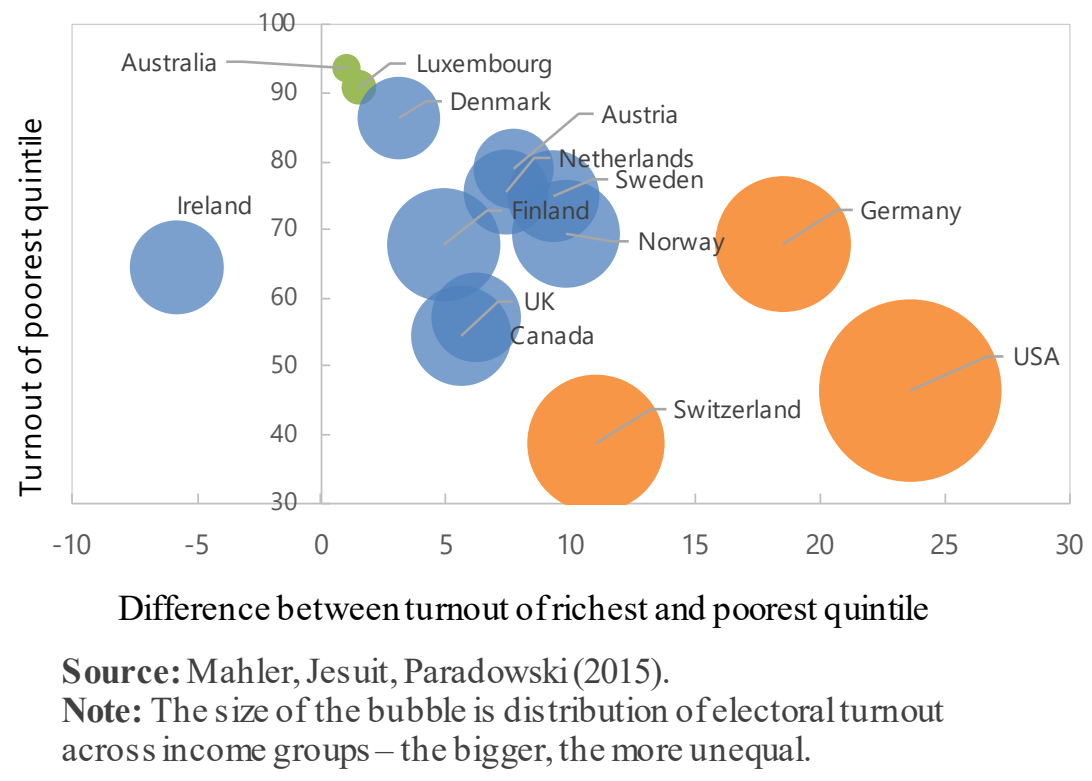

Regardless of the income levels of voters, in contexts of greater inequality, 'moneymagnified voices' can shape the political debate and consequently reduce the participation of all citizens (Ritter and Solt, 2019). Elite capture can thus reduce support for redistribution when economic elites promote policies in their business interests (Gilens and Page, 2014). ${ }^{9}$ Voting behavior and political participation of poor and rich people are likely biased by inequality through many other channels, including limited resources of the poor to engage in politics; privileged access of the rich to campaign contributions; party financing, and political representation; or incentives of political parties to target the poor (Cagé, 2018; Dabla-Norris et al., 2015; Milanovic, 2017; United Nations, 2020a).

Over time, this can result in a high share of disenfranchised citizens or a sense of "not belonging' (Sandbu, 2020). Thus, political inequality and economic inequality tend to go together, in ways more complex than the classical dichotomy between the median voter model and the Robin Hood paradox implies.

\section{B. What other factors shape preferences?}

In addition to the location of the voter along with the distribution of income, various other factors can shape preferences for redistribution. A growing literature in political economy and behavioral economics has found the following factors to be important:

- Expectations about net financial gains: From a common pool perspective, redistribution creates benefits for well-defined groups, with the cost borne by society at large. This can limit support for redistribution. Durante, Putterman, and van der Weele (2014) conclude

\footnotetext{
${ }^{9}$ On the drivers of the bargaining process among self-interested elite a ctors and its effect on policy formulation and implementation in developing countries, see World Bank(2017).
} 
from an experimental study that income maximization, risk aversion, and concerns about inefficient taxation all matter for redistribution.

- Economic conditions and risk aversion to economic shocks: Job losses and perceptions of heightened economic insecurity are associated with increased support for welfare spending (Margalit, 2013, for the United States; Martén, 2019, for Sweden). This increased support does not persist in good times. Further, the sensitivity of preferences for redistribution to economic conditions is higher for those between the ages of 18 and 24 (Guiliano and Spilimbergo, 2014).

- Habituation effects: Experiences of high inequality can increase or decrease demand for redistribution, depending on whether the experience of inequality leads to habituation by shifting the reference point or to rejection due to the first-hand experience. An experimental study by Charité, Fisman, and Kuziemko (2015) confirms the role of reference points. Roth and Wohlfart (2018) find that individuals living in highly unequal societies are less in favor of redistribution after controlling for income, demographics, unemployment experiences, and current macroeconomic conditions. Inequality experiences thus affect redistribution preferences, most likely by changing the level of inequality people accept as fair. This mechanism could explain the manifest lack of selfcorrection in many countries in the face of increasing inequality. But it also implies a role for culture and the state to shape attitudes towards redistribution.

- Beliefs about the determinants of success: Support for redistribution seems to stem from powerful commitments to fairness and reciprocity, that is, the propensity to cooperate and share but to punish those who violate cooperative social norms. ${ }^{10}$ Thus, if the beneficiaries of economic advantages believe their individual characteristics (gender, race) or luck to matter for success, they are much more likely to support redistribution to the poor than if they think the key to success is hard work and risk-taking (Figure 2). ${ }^{11}$ This explains why support for redistribution is higher when people are more pessimistic about social mobility (Alesina, Stantcheva, and Teso, 2017). On the other hand, rejection of redistribution may reflect the apparent violation of reciprocity norms by welfare programs where the recipients are perceived to be undeserving (Fong, Bowles, and Gintis, 2003).

\footnotetext{
${ }^{10}$ Opposing individual motives towards redistribution like self-oriented income maximization and otheroriented social a ffinity can co-exist, nevertheless. Cavaillé and Trump (2015) find that differentiating between redistribution as taking from the rich and redistribution as giving to the poor helps explaining this puzzling concomitance in a ttitudes towards redistribution.

${ }^{11}$ Empirica lly, a nother factor which decreases willingness to redistribute is a high degree of ra cial or ethnic fractionalization. This is especia lly true in contexts where the bottom of the income distribution comprises mostly ra cial or ethnic minorities (Alesina, Ba qir and Easterly, 1999; Alesina, Gla eser and Sa cerdote, 2001; Alesina and Gla eser, 2004; Alesina and Giuliano, 201 1; Dahlberg et. al, 2012; Mollerstrom, 2016). Alesina and Glaeser (2004), using data from 1990-2000, found that a bout half of the difference in the extent of redistribution, measured by the amount of social spending to GDP, between Europe and the United States could be attributed to variations in the degree of racial and ethnic fractionalization.
} 
Figure 2. Determinants of Support for or Opposition to Redistribution

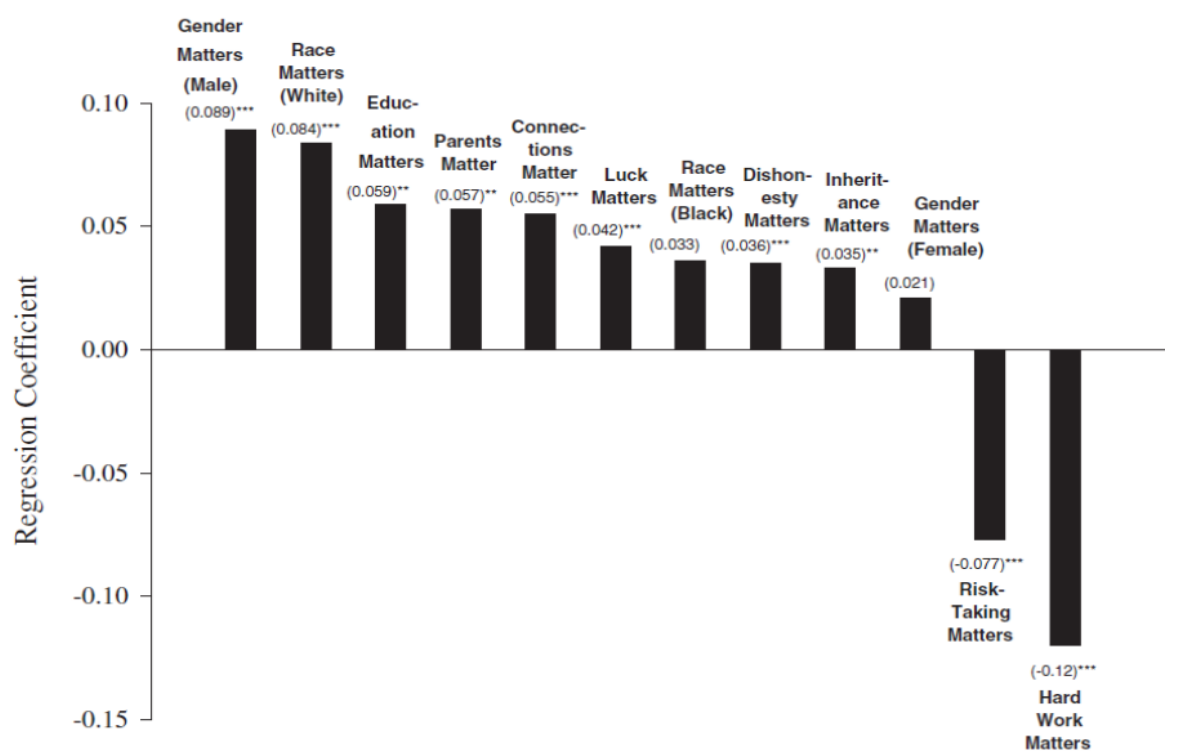

Source: Fong, Bowles, and Gintis (2003) "Reciprocity, Self-interest, and the WelfareState" in the Handbookon the Economics of Giving, Reciprocity and Altruism (2004) Part II, edited by Jean Mercier-Ythier and Serge Kolm.

Note: The chart depicts the values of the estimated coefficients (significant at $1 \%$ level) from an OLS regression using the 1998 Gallup Social Audit Survey with 5001 US respondents, predicting support for redistribution depending on beliefs a bout causes for poverty/wealth.

- Perceptions about inequality: There is increasing evidence that perceptions matter sometimes more than facts in shaping demand for redistribution (Cruces, Perez-Truglia and Tetaz, 2013; Alesina, Miano and Stantcheva, 2018; Bussolo et al., 2019; Cavaillé and Ferwerda, 2018; Karadja, Mollerstrom and Seim, 2017). These perceptions typically reflect objective macroeconomic conditions such as unemployment, the poverty rate, local and national inequality, as well as personal experience with insecurity. Experiments show that changes in perceptions are a crucial ingredient in increasing support for redistributive policies (Bastani and Waldenstrom, 2019). However, experiments also suggest that support for redistributive policies is not elastic. Kuziemko et al. (2015) use randomized online survey experiments to provide information on US income inequality, the link between top income tax rates and economic growth, and the estate tax. They find that this informational treatment strongly affects views about inequality but does not shift preferences on tax and transfer policies much, except for the estate tax, where extreme ex-ante misinformation seems to drive the results. The authors find the small effects for all other policies to be driven by the respondents' low trust in government. Decreasing trust lowers support for all poverty-alleviation policies.

The above factors may explain why there may be inconsistencies between the perceived level of income inequality, the actual level of income inequality, and demand for redistribution. ${ }^{12}$

${ }^{12}$ See Kennworthy and McCall(2008) for an examination of patterns over time for 8 OECD countries. 
After examining the supply side of redistribution, we will discuss the factors hindering the transmission of preferences into policy-making and inhibiting government responsiveness.

\section{THE 'SUPPLY’ OF REDISTRIBUTION}

Economic inequality encompasses several dimensions: wage, income, wealth, land, education, health, and intergenerational inequality. To address these, governments have a wide array of policies and instruments at their disposal. The mix of redistributive policies and instruments used in practice reflects various 'supply' factors such as the policy objectives of and trade-offs to governments; administrative capacity constraints; political systems; and the legacy of the welfare state institutions in place. These, in turn, are shaped by societal preferences for redistribution. Moreover, there are inevitably groups who stand to lose from redistribution, such that the extent of redistribution may partially reflect their respective influence in the policy choice. Thus, the questions of why some governments redistribute more and what drives their capacity to do so can be understood in this supply and demand framework.

The largest differences in redistribution are between advanced and developing economies and reflect variations in the use of tax instruments and fiscal and administrative capacity (Bourguignon, 2018). Even within advanced economies, however, there are significant variations in social contracts in terms of the weight placed on implicit and explicit redistribution policies and on the respective roles of the government and other entities (charities, churches) in improving distributional outcomes. The effectiveness of redistribution (coverage, progressivity, generosity) also differs, but it is difficult to establish given the scarcity of data, including on in-kind benefits, which would be required to enable a full incidence analysis (Lustig, 2017).

Recent policy debates have highlighted the importance of implicit redistribution ("predistribution) policies to correct the (market) income generation process to reverse the rising inequality of these past decades (Collier, 2018; Gruber and Johnson, 2019; Rajan, 2019; Sandbu, 2020). In particular, the role of governments in incentivizing capital formation and helping create good jobs has been underscored. ${ }^{13}$ Similarly, minimum wage and antidiscrimination laws have also been suggested to foster inclusive growth by improving work and training incentives for various groups (women and minority groups, for example). The role of anti-corruption strategies in reducing rent-seeking has also been emphasized.

Explicit redistribution policies nevertheless remain relevant. Theory and evidence suggest that who is taxed and who benefits from transfers matter for equality outcomes. The taxation of wealthy individuals and corporations is hotly contested because of the possible

\footnotetext{
${ }^{13}$ Interestingly, a lready in 1955, Simon Kuznets observed that when governments limit wea lth a ccumulation through policy instruments such as inheritance taxes and other capital levies, they act on a societal preference a ga in st income inequalities. He a lso a rgued for regulation to prevent capital flight as this reduces the ca pital formation required for economic growth.
} 
disincentive effect of high taxes on capital gains and profits on savings. This could be detrimental to investment, and thus, productivity and economic growth (Jones, 2019). From this perspective, the worldwide trend to reduce direct taxes exemplifies countries' internal redistributive struggles as a function of their social stratification. When upper-income groups can resist direct taxation, the capacity of governments for redistribution is limited (Kaufman and Stallings, 1991).

\section{A. Setting the stage for redistribution: Welfare States}

The modern welfare state, or how states assume responsibility for social welfare and thereby fulfill the social contract, varies widely among countries. Historical and cultural legacies of conservative, liberal, and social democratic principles shape welfare states in their current form. Important differences across welfare systems include the conditions of eligibility, the quality of benefits and services; the emphasis on means-testing versus universal access; and the rights of citizens to employment (Esping-Andersen, 1989).

This typology assists with appreciating the different roles of the government versus market and family in welfare delivery across different countries. A widely used approach distinguishes between at least three models of Welfare States ('Nordic,' 'corporatist' and 'Anglo-Saxon') according to reliance on universalism vs. targeting; reliance on markets vs. government; or the role of churches and voluntary means. The Nordic countries can be grouped in the social democratic model, which emphasizes universal access and the limited role of the private market. Anglo-Saxon countries belonging to the liberal group tend to favor minimal public intervention and a decisive role for the market, while continental European countries making up the conservative or corporatist group historically rely extensively on social insurance and family and churches as means of welfare delivery (Causa and Hermansen, 2017).

The capacity of these different welfare models to reduce inequality and poverty is likely shaped by coalitions of interest groups, while they, in turn, affect the formation of 'interests, preferences, and coalitions among citizens' (Korpi and Palme, 1998). Welfare institutions, in this view, are a key 'intervening variable' shaping distributional outcomes.

Whereas the level of social spending differs considerably between these welfare models, compared to social expenditure in developing countries, the differences appear trivial. Abstracting from differences in spending ability, which are reviewed below, the historical institutional dimension helps to shed light on the persistence of high levels of inequality in developing countries. A rich literature shows how welfare institutions, like other institutional structures, are likely influenced by colonial history, ethnolinguistic heterogeneity, and conflict and political instability. Examples include exploitative institutions in the Americas triggered by colonialization, which continued to advantage elites by providing them privileged access to political power or economic opportunities (Engerman and Sokoloff, 2002). Angeles (2007) confirms that colonialization is a major explanation for today's higher level of inequality in former colonies, likely by influencing how institutions were created. 
However, while a high level of ethnic fractionalization and a history of slavery is positively associated with high inequality, Haller et al. (2016) find that a well-functioning welfare state as measured by the level of social spending can cancel this effect out. These findings have important implications for the development of welfare institutions in developing countries.

\section{B. Measuring pro-poorness of redistribution}

Determining whether countries that redistribute more share common features in terms of their political and welfare systems is complicated by the difficulties associated with assessing both the pro-poorness of redistribution (the focus of this section) and classifying political regimes beyond the democracy-dictatorship dichotomy (section IV).

Beyond the size of government tax take and social spending,${ }^{14}$ key qualitative features of redistribution efforts are population coverage, progressivity, and generosity (Francese and Prady, 2018). The volume of social spending alone is not sufficient to qualify as a welfarestate commitment as it may disproportionately benefit a privileged few or powerful interest groups. Low expenditure on unemployment programs may reflect an effective welfare state delivering full employment. A high share of social expenditure relative to GDP may be due to high administrative expenses and inefficiencies rather than high quality. However, size matters, as do the composition of government spending, financing, and the progressivity of all the taxes and government spending combined (Lustig, 2017).

Assessing the effect of public social spending on household income is complicated. This is because in-kind benefits, indirect transfers, and indirect taxes and co-payments for health are typically not recorded in household surveys. The difference between market and net Gini, a widely used proxy for redistribution, only considers the effect of direct taxes and transfers. This underestimates the true effort and impact of government spending on the ability of a household to maintain a living standard beyond its market income. ${ }^{15}$ An important element lies in the primary purpose of in-kind transfers: to ensure equal access to good education, healthcare, and other public goods. Their effect is thus to equalize inequality's long-term effects and to prevent transmission of poverty across generations. Among OECD countries, despite little targeting of in-kind transfers to low-income households, their substantive size and their progressive incidence make them highly equalizing instruments (Causa and Hermansen, 2017).

\footnotetext{
${ }^{14}$ Social spending comprises both social protection a nd expenditure on health and education(IMF, 2019a). Socia l protection en compasses programs on (i) social a ssistance or social sa fety nets (cash tra nsfers, noncontributory pensions, food and in-kind programs, feewa iv ers, social care services etc.) (ii) socia linsurance (contributory pensions, health and other insurance such as maternity leave, paid sick leave etc.), and (iii) labor market programs (passive such as unemployment benefits, active such as training and employment incentives). Programs typically encompass both tax incentives as well as expenditure.

${ }^{15}$ Based on experimental Distributional Na tional Accounts analy sis, Causa and Hermansen (2017) report that with social transfers in kind, total household income would be 22 percent higher, on average, a cross the 9 OECD countries included in their a nalysis.
} 
In advanced economies, tax es on personal income and cash transfers to the poor, as a share of GDP, are on average about ten times higher than in low-income countries (Bourguignon, 2018). In-kind transfers are generally progressive. Among OECD countries, social spending expenditure, which contains government expenditure on social protection in cash and inkind, on average is above 20 percent of GDP, with considerable variation across countries (Figure 3). This is almost twice the level as in low-income and middle-income economies. In conformity with the worldwide trend, social spending - i.e., the welfare state - as a proportion to GDP has risen over the last twenty years. The largest public spending item is pensions, worth 8 percent of GDP across the OECD.

Figure 3. Public Social spending in the OECD (Percent of GDP)

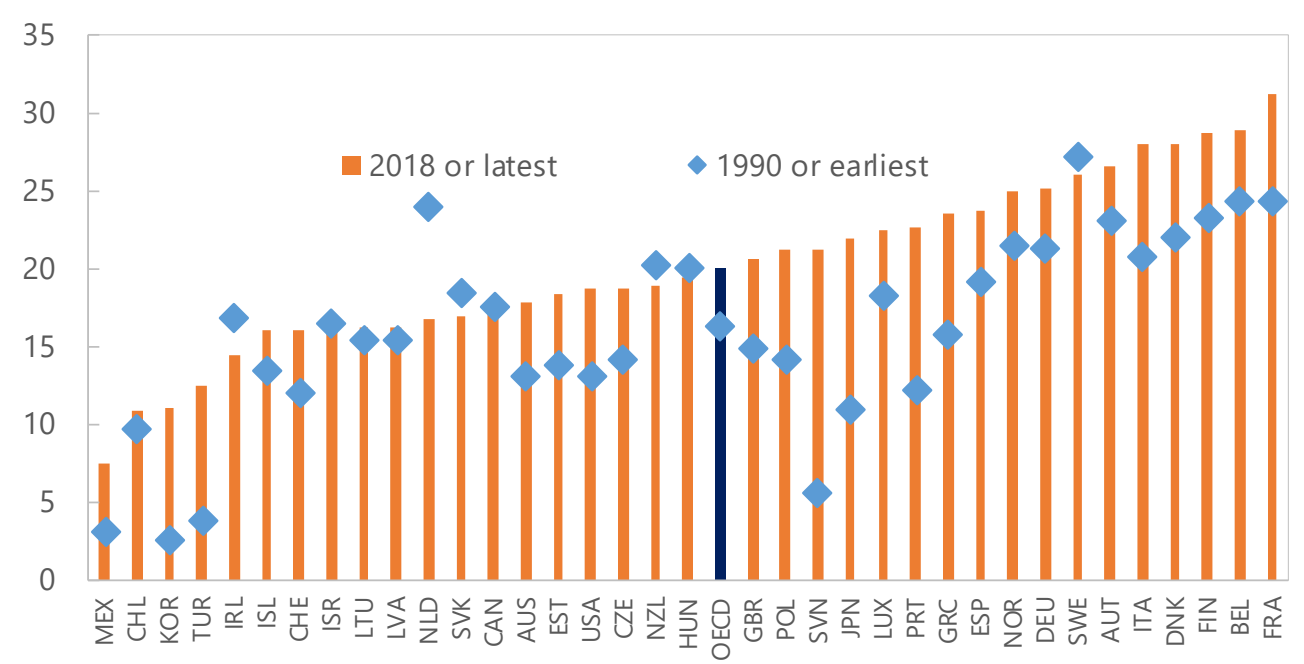

Source: OECD.

Note: Social spending includes cash benefits, in-kind services, and taxbreaks with socialpurposes.

In 2018 in the $28 \mathrm{EU}$ Member States, expenditure on social protection ${ }^{16}$ represented 18.6 percent of GDP or 40.6 percent of total expenditure. Around 90 percent of this expenditure was cash benefits and services in kind. In terms of effectiveness, a higher share of GDP on social protection tends to be associated with a lower level of inequality. ${ }^{17}$ This is in line with the negative relationship between public social protection spending and income inequality found in the literature (International Monetary Fund, 2019b).

From a cursory overview, without investigation into structural policy changes at the country level, changes in social spending do not seem to be associated with a consistent pattern of inequality changes (Figure 4). Between 2000-18, social protection spending rose in half of

\footnotetext{
${ }^{16}$ The Eurostat definitions on social expenditure are similar to the ones used by OECD, but there are differences in coverage and categorizations that explain the differences in reported shares of GDP. While the OECD-SOCX database uses ESSPROS-Eurostat data for the EU member states, OECD has own databases for health, childca re and ALMPs (OECD SOCX Manual, 2019Th).

${ }^{17}$ However, low inequality a lso exists in countries with rela tively low spending on social protection, for example in the Slovak and the Czech Republic.
} 
this sample of EU countries and fell in the remaining half. Inequality increased equally among both groups approximately two-thirds of the time. ${ }^{18} \mathrm{~A}$ more detailed analysis for seven EU countries of the effect of changes in taxes and transfers on poverty and inequality reveals that structural reforms tended to increase inequality, especially during 2007-2011implying the drawing back of safety nets at the time when they were needed and demanded most $^{19}$ (Hills et al., 2014; Eurobarometer, 2011).

Figure 4. Change in Income Inequality and Social Protection: 2000-2018

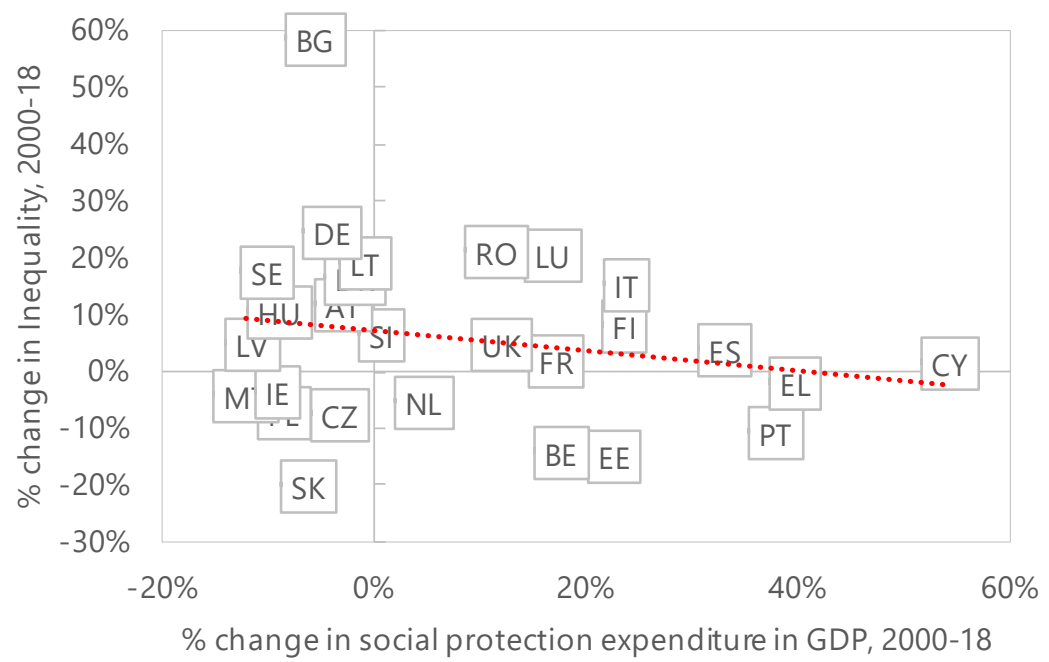

Source: Eurostat.

Note: General government total expenditure on social protection as defined by COFOG.

At the same time, the composition of social spending was changing, as cash transfers on average were reduced and in-kind support, foremost health care, increased (Causa and Hermansen, 2017). Limited fiscal space coupled with population aging may require more emphasis on health and pension spending at the expense of other social protection programs. Any reduction in inequality from in-kind support would not be captured in the disposable income at the household level, as discussed above.

More generally, both the level and composition of social spending matter for the net progressivity of government budgets. In the United States, Argentina, and Uruguay, increased social transfers offset declining top tax rates over time. In Japan, South Korea, and Taiwan Province of China, where direct transfers to the poor are limited, significant redistribution occurs via public education spending and subsidies. In countries where increased public pension benefits in social transfers crowded out equalizing expenditure on children and working-age adults, progressivity declined (Lindert, 2017).

\footnotetext{
${ }^{18}$ Note that spending-to-GDP reflects changes in economic trends (unemployment spending) a s well as contraction of GDP; in Irela nd GDP in 2015 expanded by 25 percent due to intellectual property relocating to Ireland.

${ }^{19}$ The highest political priority for European citizens in repeated special surveys between 2009 and 2011 was 'tackling exclusion and poverty'.
} 
In developing countries, in addition to historical, political, and administrative constraints, limited redistribution also reflects the composition of taxes and spending. Tax policy is typically not as effective in altering the post-tax distribution of income as in developed countries. Further, as Figure 5 shows, not only is social protection much lower, but the composition of spending and the coverage of the population through social assistance, social insurance, or labor market programs is very different. For low-income countries, the dominant source of social protection for the population is domestic private rather than public transfers. Without those, coverage of the population is below 20 percent. Similarly, adequacy of benefits, i.e., the total benefits received by all beneficiaries in the population as a share of the total welfare of beneficiaries, is much higher in developed than in developing countries. There is thus limited redistribution through fiscal policy for developing countries when compared to advanced economies (International Monetary Fund, 2017).

\section{Figure 5. Social Protection and Labor Programs (SPL)}

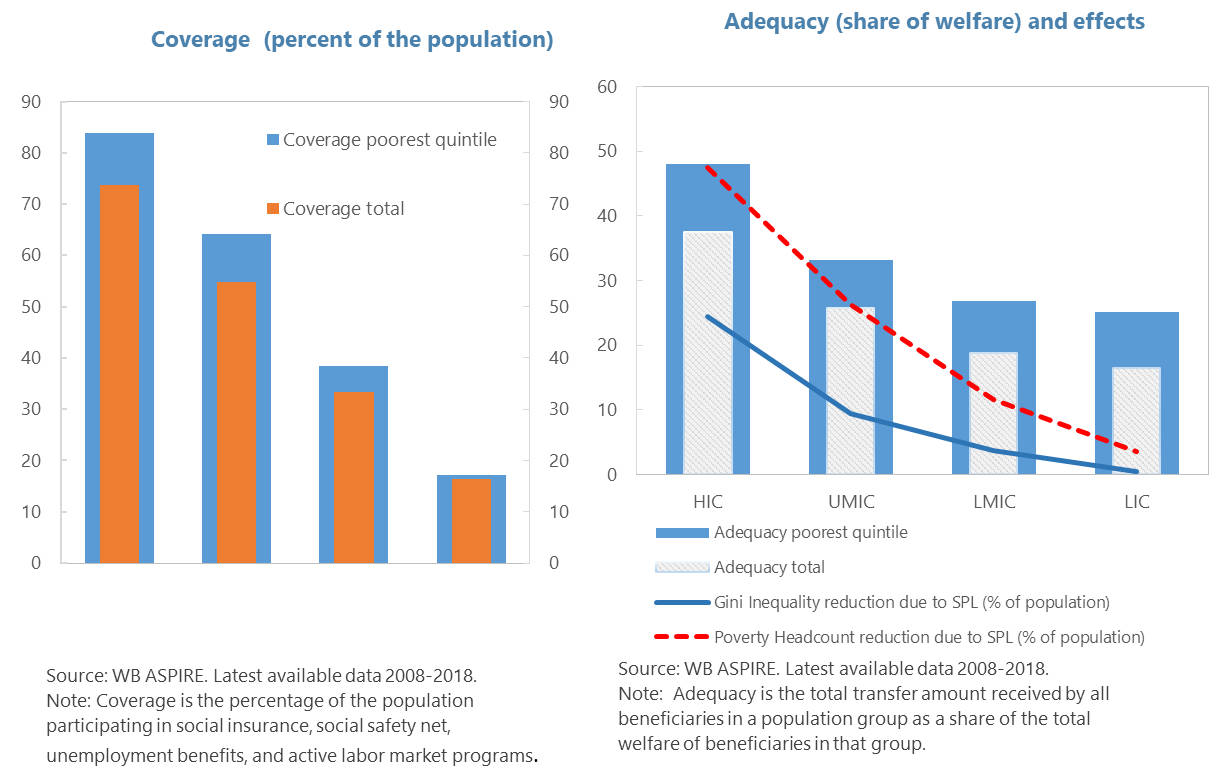

Developing countries thus mostly attempt to alter welfare through in-kind transfers such as education or health care (Davoodi et al., 2003). Using the average cost of provision to value the benefits to individuals from free education and health services, Lustig (2017) shows that, for nineteen developing countries, social spending and spending on education and health increase with market-income inequality. This improves inequality outcomes for all countries, but many of the poor are, to varying degrees, net payers into the fiscal system based on postfiscal income (after direct cash transfers, direct taxes, and net indirect taxes).

An important takeaway, therefore, is that the fiscal system can be inequality reducing, but poverty increasing. The overall impact on household wellbeing as a token of welfare state effectiveness depends crucially on the combined effect of taxation and social spending. On this account, structural factors can make the joint objectives of equality and prosperity more challenging for developing countries. The design of these policies in a mutually reinforcing 
way, on the other hand, reflects government choices that are dependent on the political system and institutional environment, as we discuss in section IV.

\section{Which Political Regimes Deliver More Redistribution?}

Sections II and III have examined how political regimes, institutions, and processes play a key role in influencing demand for and supply of redistribution by aggregating voter preferences critical to determine societal demands and matching them with the size and scope of redistributive policies offered by different political candidates, parties, and government. In this section, we examine the relationship between political regimes and redistribution, focusing on two hypotheses. The first is that electoral systems matter for coalition formation and hence outcomes. The second posits that the dynamics of inequality affect, and is affected by, changing political cleavages. In this context, we discuss the recent rise of populism and its likely sustainability.

\section{A. Redistribution under Proportional and Majoritarian Representation}

Elections are the core mechanism shaping and translating preferences in a democracy. Electoral systems affect electoral competition, the formation of coalitions, the partisan composition, and, ultimately, redistributive outcomes (Persson and Tabellini 1999, 2000, 2003; Iversen and Soskice, 2006). Proportional representation systems tend to favor governments that redistribute more than majoritarian systems. This is because proportional systems encourage coalition formation among a broad group of parties,${ }^{20}$ including those catering to the poor and labor unions. Majoritarianism, on the other hand, makes the entry of new parties difficult. Most European countries, except for France and the United Kingdom, have proportional representation systems. In the past, this has favored parties supporting more extensive redistribution and larger welfare states, traditionally voted for by voters with lower income. The United States has a majoritarian system with a greater degree of federalism and decentralization. This latter characteristic also plays a role as redistribution undertaken by lower levels of governments tends to be more fragmented. Alesina, Glaeser, and Sacerdote (2001) and Alesina and Glaeser (2004) concluded that up to half of the difference in the extent of redistribution between Europe and the United States between 1990 and 2000 could be explained by their electoral systems.

\section{B. Redistribution with Changing Political Cleavages}

Political parties represent coalitions of interest groups with shared views on government policies influencing redistribution, capital formation, or migration, amongst others. For Piketty (2018), the recent failure of the democratic processes to rein in inequality is a departure from the relatively egalitarian period between 1950-1980. A hypothesis is that political cleavages may have shifted and no longer resemble traditional class-based

${ }^{20}$ See for exa mple, Chin (2019) for recent empirical evidence that proportional representation favors broader coa litions using data for Brazil municipalities. 
coalitions. ${ }^{21}$ Analyzing long-run transformations of party systems by the level of income and education of voters in France, the United Kingdom, and the United States, he diagnoses a dissociation of lower education and lower-income voters from their traditional political representations, which today mainly represent elite voters (high income or high education). This could explain the lack of democratic response to rising inequality and the rise of populist parties supported by 'abandoned' non-elite voters, as new cleavages between "globalists" (high-education, high-income) and "nativists" or "populist" (low-education, lowincome) have emerged. A way out of the predicament requires uniting low-education, lowincome voters from different backgrounds, which is the type of political coalition that provided egalitarian policies in the past, but how and under which circumstances this is possible is less than clear.

\section{Redistribution under Populism: Then and Now}

Populist movements are hardly new, but history suggests that populists are rarely elected in good economic times. Instead, they seem to be brought about by a combination of economic, social, and political circumstances: economic insecurity, threats to national identity, and an unresponsive political system (Eichengreen, 2018).

There is no universally accepted definition, but central to the populist ideology is the programmatic distinction between the 'pure people' versus the 'others,' such as elites, established political parties, state institutions (court, parliament, a central bank, etc.), or immigrants. ${ }^{22}$ When the excessive influence of the rich becomes a frequent narrative, voters rally behind populist parties that denounce a country's elite as evil.

Populism can be prevalent both at the right as well as at the left of the political spectrum. Right-wing populist movements tend to be characterized by nativism, or the belief that nonnative inhabitants are threatening to the homogenous nation-state. Left-wing populism typically calls for a major redistribution of resources to counter economic inequality.

Between the 1940s and 1980s, left-wing populist governments were widespread in many Latin American countries but rarer in advanced economies (Dornbusch and Edwards, 1991). The recent surge in populism in many advanced and emerging economies, by contrast, has been driven by right-wing populists. In Europe, not only has the number of parties classified as a populist (Figure 6) doubled in numbers since 2000 but so has the number of governments with populist participation..$^{23}$ Whereas in early 2000 , populist parties accounted

\footnotetext{
${ }^{21}$ Economic and identity cleavages are a lso emphasized by Mukand and Rodrik (2019) and Gennaioli and Tabellini(2019).

${ }^{22}$ Authoritarianism, or the belief in a strictly ordered society with severe punishment for those opposing the order can also be a feature. See for example, Mudde(2004) Weyland(2001), Dahrendorf (2003) and Ka ltwasser (2014).

${ }^{23} \mathrm{https}$ ://institute.global/insight/renewing-centre/european-populism-trends-threats-and-futureprospects\#article-footnote- 2 .
} 
for just 7 percent of votes across the continent, in 2018, one in four voted for a populist party. ${ }^{24}$

Figure 6. Vote Shares in European Countries

(weighted by population size)

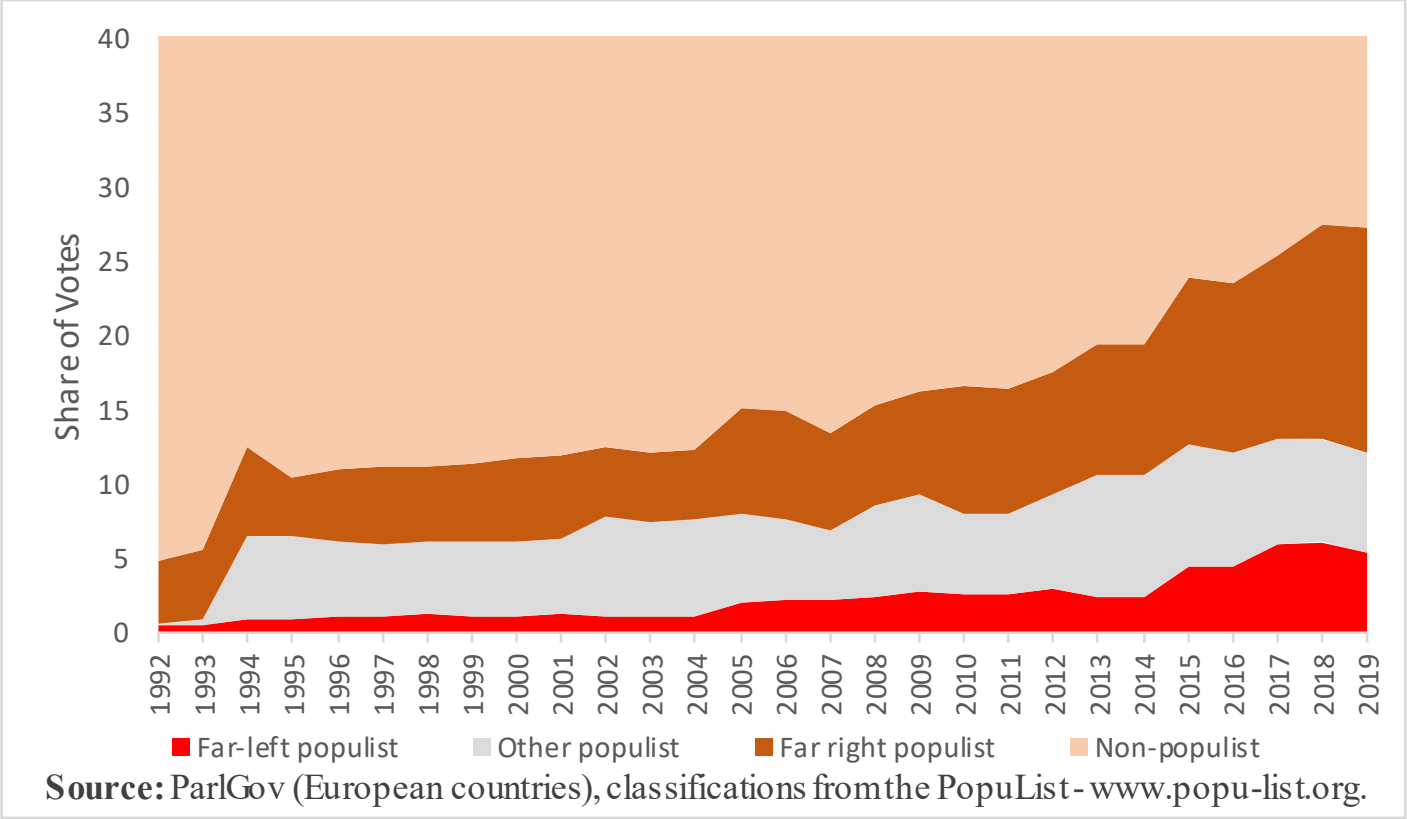

Rising inequality is a possible explanation for the rise of populism. Tabellini (2019) emphasizes inequality associated with new divisions along specific social dimensions, including education, geography, exposure to technology, and globalization. He focuses on two behavioral mechanisms to explain the success of populist parties: disappointed expectations and switching social identities. Disappointed expectations favor political risktaking by voters, leading to the emergence of more extremist parties and new parties, including populists. Buoyed by these disappointed expectations, the populist parties seek to broaden their base by adopting platforms of lower taxes and conservative cultural and social policies, which end up being supported by an unlikely coalition of "very disappointed" and "very rich" voters. ${ }^{25}$

Moreover, as losers from technology and globalization tend to be less educated and more socially conservative, economic conflicts transform into social conflicts over immigration and civil rights. These new social identities, fostered by economic dislocations, are exploited by populist parties. This proposition is partly borne out in empirical evidence. Dal Bó and others (2018) find, for example, that the rise of the Sweden Democrats, a far-right party, can be explained by the growing support of voters facing greater income decline and job insecurity over time. Inglehart and Norris (2016), on the other hand, using data from the

\footnotetext{
${ }^{24} \mathrm{https}$ ://www.theguardian.com/world/ng-interactive/2018/nov/20/revealed-one-in-four-europeans-votepopulist.

${ }^{25}$ This idea echoes Alga net a l. (2018) who argue that the 2017 French presidential elections illustra te a collapse of the tra ditional left-right a xis. Using monthly survey data from 17000 panelists, they show that this phenomenon can be explained by subjectivevariables such as life sa tisfaction and interpersonal trust.
} 
pooled European Social Survey 1-6(2002-2014), find evidence of a 'cultural backlash' largely fueled by immigration. Redistributive concerns still matter, though: insofar as adverse economic conditions increase competition for government funds, nativism will object to granting economic benefits to outsiders.

\section{Redistribution under Populism: The Outcome}

As to the consequences of populism, a study of Latin America's history is instructive. Edwards (2019) draws a distinction between past 'classical' populist episodes, mostly occurring before the 1990s, and the 'new' populism, which appeared after the 1990s in Latin America and is now gaining momentum in other parts of the world. Classical populists mostly came to power and were forced out by non-democratic means. Their focus was on redistribution through money creation and expansionary fiscal policies. The 'new' populism, Edwards argues, is different in that it has occurred under democracy and focuses on microeconomic issues such as regulations, protectionist measures, expansion of the public sector; and, mandatory minimum wages. De Bolle and Zettelmeyer (2019) also note recent shifts in voter preferences that embrace, in addition to trade restrictions, other policies classified as 'economic nationalism' such as restrictions of foreign direct investment, bans on immigration, and withdrawal from multilateral organizations. Another feature of this 'new populism,' in Latin America at least, has been the recourse to constitutional amendments to achieve distributional objectives.

The final days of the 'classical' populist experiences in Argentina, Brazil, Chile, Mexico, Peru, and Nicaragua, display 'the self-destructive feature of populism.' Expansionary policies and inflationary spending brought immediate gains, but they ended with macroeconomic crises characterized by high inflation, capital flight, and sharp declines in real wages and per capita income (Dornbusch and Edwards, 1991). Ultimately, these policies hurt growth and did not achieve lasting redistribution and inequality reduction (Cardoso and Hellweger, 1991; Edwards, 2019).

The inclusive growth record of 'new' populist regimes in Latin America remains mixed. In Bolivia, under populist leadership between 2006-19, extreme poverty nearly halved; growth and infrastructure investment were strong; the currency was stable, and inflation remained low. It is noteworthy, however, that poverty and inequality outcomes improved broadly during this period in Latin America, including in countries with non-populist governments. Importantly, subsequent political developments in Bolivia ${ }^{26}$ cast doubt on the ability of the 'new' populism to sustain inclusive growth. While it is too early to assess the effects on growth outcomes, and much depends on country circumstances, policy design, and actual implementation, the historical experience would weigh the risks to inclusive growth higher than the opportunities.

\footnotetext{
${ }^{26}$ https://www.theguardian.com/world/2019/mar/07/how-a-populist-president-helped-bolivias-poor-but-builthimself-a-palace; https://www.theguardian.com/world/2019/nov/17/bolivia-more-volatile-than-ever-aspresident-flees-and-leaders-denounce-a-coup.
} 


\section{E. A Tipping Point?}

Is the growing attraction of voters to populist parties reversible? If their rise was predominantly driven by economic forces, stronger growth and rising wealth for the leftbehind segments of the population could help restore votes to the political middle. The underlying dynamics, however, do not make this outcome likely.

Political betrayal of the voters appears widespread, under both 'classical' and 'new' populism. Redistributive rhetoric camouflages policies in line with the interests of the elite (Acemoglu et al., 2015). To raise voter turnout, populist movements behave opportunistically or use strategic extremism, for example, division on religious values (Glaeser et al., 2005). Paradoxically, the lack of results can make populism self-sustaining as populist governments are able to harness popular discontent against the media, immigrants, or experts. Angry voters are more easily distracted (Johnson, 2019a and 2019b), and as individuals adjust to prevailing circumstances, discontent with populist politicians grows only moderately despite rising inequality (Roth and Wohlfart, 2018). This may explain why populism is associated with leaders' prolonged stay in power, weakened checks on government powers, and restrained civil rights such as freedom of the press or political participation (Kyle and Mounk, 2018a and 2018b). Shifts in economic and identity cleavages through economic shocks or political strategies employed by groups contending for power ${ }^{27}$ could lead to conflicts. To the extent these overshadow redistributive concerns, political systems can enter a bad equilibrium. In this environment, government policies do not counter the underlying economic forces driving market inequality, as voters are distracted by identity conflicts. Rather, increasing inequality can reinforce the identification of the voters with new platforms against their economic interests and act as a stabilization of the political regime.

Taking a long-term perspective, for the first time in history, there are more democracies than non-democracies. The number of countries that score the maximum value on the respective indicator, however, has been stagnant and recently declining (Figure 7). Consequently, the gap between high-scoring democracies and democracies just above the threshold has been growing.

\footnotetext{
${ }^{27}$ See Mukand and Rodrik (2019). Guiso et a l. (2017) find that economic insecurity destroys trust and fosters a dverse attitudes towards immigra nts. Further, voters change their beliefs and preferences when economic shocks create new cleavages (Gennaioli and Tabellini, 2019).
} 


\section{Figure 7. Evolution of Democracies and Autocracies since 1800}

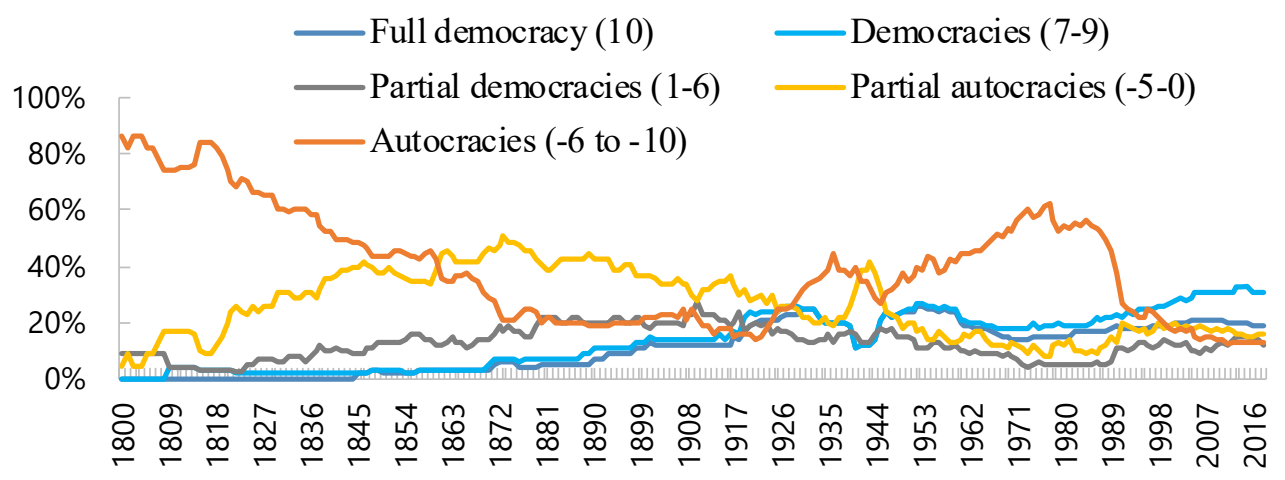

Source: Polity IV Database(www.systemicpace.org/inscrdata.html), polity 2 indicators.

Note: The maximum score for democracy is 10; a full autocracy scores -10 .

Governments' willingness to address inequality needs to be matched by their ability to deliver a better livelihood for their citizens. Safeguarding against a potential democratic backslide, from this perspective, requires not only strengthening political representation and democratically debating and solving essential policy issues. Capably addressing the needs of the most vulnerable segments of society inclusively and sustainably while managing existing constraints and questions of political feasibility will be an important part of the answer to the populist challenge. Inclusive rather than divisive political strategies will be decisive for lowering economic and identity cleavages and keeping the very fabric of liberal democracies alive.

\section{THE 'HOW' AND 'WHEN' OF REDISTRIBUTION}

The degree of inequality in an economy depends on its structure or people's endowments and the value earned with these endowments. Latin America's proneness to populist cycles, for example, has been attributed to the formation of a landed elite or export oligarchies in the second half of the nineteenth century that led to a persistently high concentration of income and assets (Kaufman and Stallings, 1991).

\section{A. 'Pre-distribution' versus 'Redistribution'}

'Pre-distribution,' or implicit redistribution, affects endowments and can be influenced by "market reforms that encourage a more equal distribution of economic power and rewards even before government collects taxes or pays out benefits" (Hacker, 2012). Redistribution, in contrast, hinges on taxing 'winners' to fund programs that compensate 'losers.' Such measures, Kuttner (2018) observes, are only "second bests. They do not foster social cohesion: winners resent the loss of earnings; losers, the loss of dignity". This view is echoed by Rodrik and Sabel (2019): "Ex post redistribution through taxes and transfers accepts the productive structure as given, and merely ameliorates the results through handouts". 
In his 15-point proposal in response to 'Inequality: What Can be Done? ${ }^{28}$, the late Sir Tony Atkinson called for several pre-distribution policies, including public employment; minimum wages, encouraging innovation that increases the opportunities for employment; and competition policies with a distributional dimension. Renewed calls have been made recently for greater weight on pre-redistribution policies relating to technological change (Acemoglu, 2020), competition policies (Aghion, Cherif, and Hasanov, 2021), and minimum wages, education, and retraining for workers (Sandbu, 2020).

The appropriate mix of pre-redistribution and redistribution policies will necessarily vary across countries, reflecting their specific circumstances. Rodrik (2019) offers a useful taxonomy, suggesting that pre-redistributive and redistributive measures depend on whether countries target inequality at the bottom, middle, or top of the income or wealth distribution. Universal basic income, health, and education increase endowments, consistent with predistribution interventions, focus on the bottom of the distribution. By contrast, greater antitrust regulation and wealth taxes target the top of the distribution.

In practice, there can be important financing and political feasibility constraints for both predistribution and redistribution. In what follows, we discuss these constraints with respect to redistribution and climate change legislation.

\section{B. What are the constraints?}

Are there limits to redistribution? From an economic point of view, the obvious starting point is the potential trade-off between economic performance (efficiency) and income equality in the sense of Okun's 'leaky bucket' metaphor. Efficiency losses due to redistribution are thought to rise with the amount of redistribution. Andersen and Maiborn (2016) revisit the issue and find that, along the efficiency frontier (under stochastic frontier analysis), for a sample of OECD countries between 1980 and 2010, the trade-off exists. For countries below the efficiency frontier, they confirm the positive correlation between income equality and economic performance found by Ostry et al. (2014). This implies scope for most countries to improve both economic performance and equality.

Turning to political limits, a theory relating to elite capture is the 'political-loser hypothesis' Acemoglu and Robinson (2000b). It predicts that those groups that stand to lose political power from a technological or economic change and have power will block it. Those agents that are economic losers but have no political power cannot prevent the change. Thus, reforms that may be beneficial to many can be resisted by few. Applied to changing an existing redistributive system, the distribution of political power is important, as well as identifying winners and losers from a proposed reform. Concentrated losses and dispersed benefits are obstacles to reform. Uncertainty about the distribution of gains and losses similarly leads to a status quo bias (Fernandez and Rodrik, 1991).

${ }^{28}$ https://www.tony-atkinson.com/the-15-proposals-from-tony-atkinsons-inequality-what-can-be-done/ 
Climate policy brings into sharp relief these issues. Climate change generates significant externalities at the national and global levels, requiring international agreements on mitigation supported by country-level measures. Poorer households and countries, which contribute less to climate change, are those most at risk from its effects. Climate change also has important implications for intergenerational equity as climate inaction now adversely affects future generations. Conversely, the costs of climate mitigation will be primarily borne by current generations, while its benefits will mostly accrue in the future. Concentrated losses and dispersed benefits, coupled with the short policy horizons of national governments, ${ }^{29}$ dampen the effectiveness of collective action at the national and global level. Ideological divides on the science of climate change among political parties seem to play a lesser role in explaining differences in legislative climate action. Fankhauser, Gennaoili, and Collins (2015), for example, find no significant differences in climate legislation between left-wing and right-wing governments, except in a few Anglo-Saxon countries where rightwing governments have affected the passing of climate legislation.

\section{Lessons from International Experience}

Political feasibility continues to be the biggest obstacle to reforms. In the short run, their distributional consequences can dwarf the expected gains, making them politically costly (Ciminelli et al., 2019; Chen et al., 2019). Thus, in practice, politicians often implement reforms strategically: using crises as 'windows of opportunity to push through reforms; sequencing reforms to identify winners and losers and implement the easiest ones first; or using divide-and-rule tactics that involve building coalitions with the winners (Roland, 2002).

A selective review of country experiences suggests that the careful timing and design of reforms and a good communications strategy can reduce political barriers to reforms. Specifically:

Economic crises can favor reforms, but not always. An influential study by Alesina and Drazen (1991) modeled economic stabilization as a distributional conflict, explaining delays by a war of attrition between various interest groups. The model implies that crises can help reconcile political views and generate support for reform. Alesina, Ardagna, and Trebbi (2006), analyzing inflation and fiscal stabilization, find empirical support for this idea.

Subsequent research, however, suggests that there is no systematic evidence on the catalyzing effect of crises: history abounds with examples of crises that spurred reforms and those which did not. ${ }^{30}$ Much depends on the effect of the crises on the political equilibrium (Robinson, 2009) and the type of reform (Ciminelli et al., 2019). Long-lasting tax reforms, for example, are mostly observed in 'good times' (IMF, 2013b; Chen et al., 2019), and weak macroeconomic conditions, especially low growth and high inflation, are frequent barriers to energy subsidy reforms (Clements et al., 2013).

${ }^{29}$ See for exa mple, IMF (2019c), 'How to mitigate ClimateChange', Fiscal Monitor (October).

${ }^{30}$ Robinson(2009) and Eurogroup (2020). 
Adapting the sequence and pace of reforms to the level of social consensus and government commitment can help. Limited social consensus and government commitment act as powerful barriers to reform, and weak institutions hinder implementation (World Bank, 2000). Thus, focusing on delivering only key interventions in periods of low public support and government commitment while laying the groundwork for further reforms and waiting for windows of opportunities can be viable strategies. Elections can create such windows as reforms tend to be less costly early in an incumbent's term (Ciminelli et al., 2019). In the Philippines, for example, the World Bank (2015) notes that the aftermath of the 2010 Presidential elections opened the way for greater focus on poverty and the successful expansion of a pilot conditional cash transfer program.

Reforms that include mitigating measures tend to generate more support. Opposition to reforms can arise from uncertainty about the distributional effects of reforms or low confidence in the ability of the government to protect the most vulnerable. Compensating measures can thus help reduce resistance. In Indonesia, for example, the implementation of fuel subsidy reforms in 2005 and 2008, after previous unsuccessful attempts, was aided by mitigation measures, including an unconditional cash transfer program (Clements et al., 2013). The ability to do so, however, depends on a country's fiscal situation. The bundling of reforms into comprehensive packages can also help the distributional effects from individual measures net out. This was the case, for example, in Italy's 2014 labor market reform, which combined more flexible employment regulations with an increase in the coverage and duration of unemployment benefits and more effective active labor market policies (Eurogroup, 2020).

Reform design can make a difference. While some reforms can both reinforce growth and reduce inequality, others involve trade-offs. For instance, fiscal consolidation without increasing inequality has proven to be challenging. A review of 27 fiscal adjustments in advanced and emerging Europe between 2002 and 2007 showed that market inequality typically increased due to lower output and employment; the composition and pace of the fiscal consolidation determined the effect on disposable income inequality. The increase in inequality was greater when more regressive taxes were raised, and progressive spending was cut (International Monetary Fund, 2014). Inequality tends to rise as lower-income groups are disproportionately affected by cuts in social benefits and lower public sector wages. Progressive taxation, protection of social benefits for vulnerable groups, or promoting education and training for low- and middle-income workers can mitigate these effects (International Monetary Fund, 2013a).

\section{Broad public consultations underpinned by a good communications strategy are crucial.}

Consultations and communications are no substitute for good policies, but reforms are more likely to be derailed if they are not properly understood or accepted (Stankova, 2019). Wide public consultations, supported by clear and transparent communications, are critical to building political cohesion and buy-in for reforms. This is especially important in an environment characterized by low trust in government, hyper-connectedness and 
increasing expectations about transparency, and widespread 'fake news.' The strategic use of public consultations and communications was a key success factor behind the 2010 Danish tax reform. The reform was announced years in advance, creating time for consultations; a tax commission was established to champion the reform; and public communication was broadly used -including by presenting the tax commission's report live on TV (OECD 2010, Annex A). In Iran, a broad public relations campaign was used to explain that the 2010 subsidy removal aimed to reduce excessive consumption and smuggling and that cash transfers would be introduced to mitigate its impact (Clements et al., 2013; Coady, Parry, and Shang, 2018).

\section{The COVID-19 Pandemic: A Game Changer?}

Before the COVID-19 pandemic, the context for redistributive reform was one in which a series of global forces would further widen economic inequalities. Mckinsey Global Institute (2017) identified six megatrends that would severely test inclusive growth models and the social contract in the European Union: demographics; digital technology, automation, and artificial intelligence (AI); increased global competition; migration; climate change and pollution; and shifting geopolitics. In developing countries, population growth, the dislocating effects of structural transformation, and vulnerability to climate change were seen as threats to the position of lower-income groups.

The COVID-19 crisis has exposed and exacerbated long-standing societal inequities (Case and Deaton, 2020). The virus has exacted a heavy toll across the world in terms of loss of human lives and economic disruptions. Moreover, its impact has fallen disproportionately on lower-income individuals and groups and those whose jobs are less amenable to teleworking (Brussevich, Dabla-Norris, and Khalid, 2020). Projections suggest inequities could rise further, with significant increases in the number of people living in poverty (Furceri, Loungani, and Ostry, 2020; Sumner, Ortiz-Juarez and Hoy, 2020). There is uncertainty about how long-lasting the pandemic's effect will be, however (International Monetary Fund, 2020). Experience with the Great Depression and the Great Recession shows that when governments increased health care and social protection, inequality declined after the initial increase (United Nations, 2020b). Indeed, the response of the public benefits scheme in Spain substantially mitigated the effect of COVID-19 on inequality (Aspachs et al., 2020).

The policy response by governments is likely to be constrained in many countries by low growth, high government debt, and declining trust in public institutions. The resulting unmet demand or disappointed expectations can compound existing discontent and distrust and fuel social unrest. Nevertheless, this need not be an inevitable outcome. Florini and Sharma (2020) suggest that societal responses, including notably growing attention to the social value and compensation of service workers, provide some indications on how to achieve more resilient polities based on renewed social trust. Many economists have also argued that the recent public discontent could lead to a rethink of capitalism (Collier, 2018; Wolf, 2020). In turn, this could generate a new consensus about the role of the post-pandemic government 
and social contracts in developed and developing economies alike (Acemoglu and Robinson, 2019; Buiter, 2020; De Bolle; 2020; Case and Deaton, 2020; Mazzucato and Skidelsky, 2020; Rajan, 2020).

\section{E. Policy Options}

The precise shape of new social contracts will be country-specific, but from the growing literature, we identify emerging support for a welfare state that invests in people, stimulates them to be active, and protects them when needed. ${ }^{31}$ This necessitates policy interventions in three broad areas: investing in 'local communities'; helping the creation of 'good jobs'; and improving processes of deliberations and communications to rebuild trust in public institutions.

Greater recognition of the limitations of conventional policy tools has led to increasing calls for local solutions. McChrystal et al. (2015), for example, emphasize 'empowered selforganization,' that is, bottom-up, self-organized action by individuals to complement responses of central governments. Rajan (2019) argues that big technological revolutions upset the equilibrium between three pillars: the political structure (governments), the economic structure (markets and firms), and the sociological or human structure (communities). The resulting anxiety and conflict can lead to populism. The idea that populism may be the response to weakened social ties or solidarity between individuals is also articulated in Collier (2018). Local communities (neighborhoods, villages, local governments) have a pivotal role to play in providing safety nets to individuals and reducing spatial disparities. Empirical analysis by Boeri et al. (2018), based on European and Latin American Barometer data, provides indirect evidence in support of this hypothesis and highlights the importance of civil society. Rajan gives the example of Pilsen, an area of Chicago that was once crime and drug-ridden but attracted new residents following revitalization through community efforts. In the United Kingdom, until 2013, the city of Preston faced severe challenges of deindustrialization and destitution, but its fortunes improved noticeably when the local city council started investing in local businesses and job creation to fill in the gap for a dwindling private sector. ${ }^{32}$ This 'inclusive localism'investing in communities with economically viable opportunities and lowering barriers to entry into those, Rajan suggests, is an alternative to the new populism.

Job creation is another essential ingredient. Gruber and Johnson (2019), for example, argue for the need for massive public investment in breakthrough science outside of the five urban cores or superstar cities in the United States. ${ }^{33}$ They suggest that investment in other cities with a high concentration of educated young people, inexpensive housing, short commutes, low crime rates, and strong university science and engineering education can help create industries of the future and support broad-based job creation and growth. Rodrik and Sabel

\footnotetext{
${ }^{31} \mathrm{http} / / /$ www.gini-research.org/articles/home.

${ }^{32}$ https://www.theguardian.com/commentisfree/2018/jan/31/preston-hit-rock-bottom-took-backcontrol?CMP $=$ share btn tw

${ }^{33}$ Silicon Valley, the New York City a rea, Greater Boston, Los Angeles, and Wa shington, D.C.
} 
(2019) make a similar call for government intervention to build "a good jobs economy"increasing overall employment opportunities in the formal sector and providing key labor protection.

Good communication on policies and reforms to the political system that favor broad participation and increases government legitimacy has also been emphasized. 'Multi-layered governance' or 'whole-of-society' solutions where policymakers collaborate with experts, the public, and other stakeholders (Florini and Sharma, 2020) are especially important at a time of declining trust in public institutions (Stankova, 2019).

\section{CONCLUding ReMARKS}

The interactions between individual preferences, politics, and economics are complex and multifaceted. Disentangling them is important to explain patterns of inequality and redistribution and to inform debates on inclusive growth. The growth that is more equitably distributed and creates opportunities for all is a key ingredient to prevent lasting damage from populist movements (Eichengreen, 2018). Evidence suggests ${ }^{34}$ that the best-performing countries in terms of economic, employment, social cohesion, and equality outcomes have in common a welfare state that invests in people, stimulating and supporting them to be active and adequately protecting them and their children.

From such a perspective, a widening of the income distribution is a failure of the political and social systems to protect the already weak position of the low-income shares (Kuznets, 1955). People's experience of deprivation matters and these are concrete, not abstract (Piven and Cloward, 1993). The core challenge, then, lies in creating a political system where all who benefit from such high social cohesion have a say in shaping it and continue to do so over decades. A big part of this requires education, mobilization, and organization of voters to prioritize their economic interests (Berman, 2019).

While there are more open questions than definite answers, part of the way forward is to actively search for solutions that work. Some of those may be local, but they will need to be complemented by policies that favor the creation of 'good jobs' and improve deliberations and communications to rebuild trust in public institutions.

\footnotetext{
${ }^{34} \mathrm{http}: / /$ www.gini-research.org/articles/home.
} 


\section{REFERENCES}

Acemoglu, Daron, 2020. "Remaking the Post-COVID World." Sixth Richard Goode Lecture. International Monetary Fund.

https://www.imf.org/external/mmedia/view.aspx?vid=6214241 193001

Acemoglu, Daron, and James A. Robinson. 2000a. "Why Did the West Extend the Franchise? Democracy, Inequality, and Growth in Historical Perspective". The Quarterly Journal of Economics, 15/4/2000: 1167-1199.

2000b. "Political Losers as a Barrier to

Economic Development”. The American Economic Review, Vol. 90, No. 2: 126130. 2013. Why nations fail: The origins of power,

prosperity, and poverty. Crown Books. 2019. The Narrow Corridor: States, Societies

and The Fate of Liberty. Penguin Press.

Acemoglu, Daron, Georgy Egorov, and Konstantin Sonin. 2013. "A political theory of populism.” The Quarterly Journal of Economics 128, no. 2: 771-805.

Acemoglu, Daron, Suresh Naidu, Pascual Restrepo, and James A. Robinson. 2015. "Democracy, Redistribution and Inequality." Chapter 21 in The Handbook of Income Distribution, Volume 2B.

Aghion, Philippe, Reda Cherif and Fuad Hasanov. 2021. "Fair and Inclusive Markets: Why Dynamism Matters," IMF Working Paper 21/29.

Aidt, Toke, Dutta, Jayasri, and Loukoianova, Elena. 2006. "Democracy comes to Europe: Franchise Extension and Fiscal Outcomes 1830-1938." European Economic Review 50(2): 249-283.

Alesina, Alberto, Silvia Ardagna and Francesco Trebbi. 2006. "Who Adjusts and When? The Political Economy of Reforms”. IMF Staff Papers. Vol 53 (Special Issue):1-29.

Alesina, Alberto, Reza Baqir, and William Easterly. 1999. "Public Goods and Ethnic Division.” The Quarterly Journal of Economics, Vol. 114, No. 4: 1243-1284.

Alesina, Alberto and Allan Drazen. 1991. "Why are Stabilizations Delayed?" The American Economic Review. Vol. 81(5):1170-1188. 
Alesina, Alberto, Edward Glaeser, and Bruce I. Sacerdote. 2001. "Why Doesn't the United States Have a European-Style Welfare State?" Brookings Papers on Economic Activity 2: $187-254$.

Alesina, Alberto, Edward Glaeser, and Edward Ludwig Glaeser. 2004. Fighting poverty in the US and Europe: A world of difference. Oxford University Press.

Alesina, Alberto, and Paola Giuliano. 2011. "Preferences for redistribution." In Handbook of social economics, Vol. 1:93-131. North-Holland.

Alesina, Alberto, Stantcheva, Stefanie, and Edoardo Teso. 2017. "Intergenerational mobility and preferences for redistribution." No w23027. National Bureau of Economic Research.

Alesina, Alberto, Armando Miano, and Stefanie Stantcheva. 2018, "Immigration and Redistribution”. No w24733. National Bureau of Economic Research.

Algan, Yann, Elisabeth Beasley, Daniel Cohen and Martial Foucault. 2018. "The rise of populism and the collapse of the left-right paradigm: Lessons from the 2017 French presidential election", CEPR Discussion Paper 13103.

Amat, Francesc, and Pablo Beramedi. 2020. "Democracy under High Inequality: Capacity, Spending, and Participation.” The Journal of Politics. Vol 82 (3): 859-78.

Andersen, Torben M., and Maibom Jonas. 2016. "The big trade-off between efficiency and equity - is it there?" CEPR Discussion Paper 11189.

Angeles, Luis. 2007. "Income Inequality and Colonialism.” European Economic Review, Elsevier, vol. 51(5): 1155-1176.

Aspachs, Oriol, Durante, Ruben, Graziano, Alberto, Mestres, Josep, Montalvo, Jose G., Reynal-Querol, Marta. 2020. "Real-Time Inequality and the Welfare State in Motion: Evidence from COVID-19 in Spain.” CEPR Discussion Paper No. DP15118.

Atkinson, Anthony B. 2015. Inequality: What Can Be Done? Harvard University Press.

Bastani, Spencer, and Waldenström, Daniel. 2019. "Salience of Inherited Wealth and the Support for Inheritance Taxation” CEPR Discussion Paper No. DP13484.

Benabou, Roland. 2000. "Unequal Societies: Income Distribution and the Social Contract." American Economic Review 90(1): 96-129. 
Berman, Sheri (2019), "The downsides and dangers of economic determinism," Social Europe, September 23, 2019; https://www.socialeurope.eu/the-downsides-and-dangers-ofeconomic-determinism.

Boeri, Tito, Prachi Mishra, Chris Papageorgiou, and Antonio Spilimbergo. 2018. "Populism and Civil Society." IMF Working Paper 18/245.

Bourguignon, François. 2018. The Globalization of Inequality. Princeton University Press.

2018. "Spreading the Wealth." Finance and Development, Vol 55

Issue 1. https://www.imf.org/external/pubs/ft/fandd/2018/03/bourguignon.htm

Brussevich, Mariya, Dabla-Norris, Era, and Khalid, Salma. 2020. "Who Will Bear the Brunt of Lockdown Policies? Evidence from Tele-workability Measures Across Countries". Working Paper 20/88. International Monetary Fund.

Buiter, Willem H. 2020. "Paying for the Covid-19 pandemic will be painful”, Financial Times, May 15, 2020.

Bussolo, Maurizio, Ferrer-i-Carbonell, Ada, Giolbas, Anna Barbara, and Torre, Ivan. 2019. "I Perceive Therefore I Demand: The Formation of Inequality Perceptions and Demand for Redistribution," Policy Research Working Paper Series 8926, The World Bank.

Cagé, Julia, 2018. Le prix de la Démocratie. Fayard.

Causa, Orsetta, and Hermansen, Mikkels. 2017. "Income redistribution through taxes and transfers across OECD countries", OECD Economics Department Working Papers, No. 1453. http://www.ecineq.org/ecineq paris19/papers EcineqPSE/paper 154.pdf.

Cardoso Eliana and Ann Hellweger. 1991. "Populism, Profligacy, and Redistribution." In Dornbusch and Edwards (eds.) The Macroeconomics of Populism in Latin America.

Case, Anne, and Deaton, Angus. 2020. “The United States of Despair”. Project Syndicate, June 15, 2020.

Cavaillé, Charlotte, and Trump, Kris-Stella. 2015. “The Two Facets of Social Policy Preferences," Journal of Politics, 77(1).

Cavaillé, Charlotte, and Jeremy Ferwerda. 2018. "How Distributional Conflict over In-Kind Benefits Generates Support for Anti-Immigrant Parties.” Working Paper. 
Charité, Jimmy, Fisman, Raymond, Kuziemko, Ilyana. 2015. "Reference points and redistributive preferences: experimental evidence." No.w21009. National Bureau of Economic Research.

Chen, Chuling, Era Dabla-Norris, Jay Rappaport, and Alekzandra Zdzienicka. 2019.

"Political Costs of Tax-based Consolidations." IMF Working Paper 19/298.

Chin, Moya. 2019. When Do Politicians Appeal Broadly? The Economic Consequences of Electoral Rules in Brazil.

Ciminelli, Gabriele, Davide Furceri, Jun Ge, and Jonathan D. Ostry. 2019. “The Political Cost of Reforms." IMF Staff Discussion Note SDN19/08.

Clements, Benedict, David Coady, Stefania Fabrizio, Sanjeev Gupta, Trevor Alleyne, and Carlo Sdralevich. 2013. Energy Subsidy Reforms: Lessons and Implications. International Monetary Fund, Washington DC.

Coady, David, Ian W. H. Parry, and Baoping Shang. 2018. "Energy Price Reform: Lessons for Policymakers," Review of Environmental Economics and Policy. 12: 197-219.

Collier, Paul. 2018. The Future of Capitalism: Facing the New Anxieties. Allen Lane.

Cruces, Guillermo, Perez-Truglia, Ricardo, Tetaza, Martin. 2013. "Biased perceptions of income distribution and preferences for redistribution: Evidence from a survey experiment." Journal of Public Economics. Vol. 98, Feb. 2013, p.100-112.

Dabla-Norris, Era, Kalpana Kochhar, Nujin Suphaphiphat, Frantisek Ricka, and Evridiki Tsounta. 2015. "Causes and consequences of income inequality: A global perspective." IMF Staff Discussion Note SDN15/13.

Dal Bó, Ernesto, Fredeico Finan, Olle Folke, Torsten Persson, and Johanna Rickne. 2018. "Economic Loser and Political Winners: Sweden's Radical Right.” Working Paper.

Dahlberg, Matz, Karin Edmark, and Heléne Lundqvist. 2012. "Ethnic diversity and preferences for redistribution." Journal of Political Economy 120, no. 1: 41-76.

Dahrendorf, Ralf. 2003. "Acht Anmerkungen zum Populismus.” Transit 25. Europäische Revue. Published 18 September 2007.

https://www.eurozine.com/acht-anmerkungen-zumpopulismus/ 
Davoodi, Hamid, Edwin R. Tiongson, E.R. and Sawitree S. Asawanuchit. 2003. "How useful are benefit incidence analyses of public education and health spending?". IMF Working Paper 03/227.

De Bolle, Monica. 2020. Basic Income Scheme for the Developing World. Financial Times May 18, 2020.

De Bolle, Monica, and Jeromin Zettelmeyer. 2019. "Measuring the Rise of Economic Nationalism.” Peterson Institute for International Economics Working Paper No. 19-15.

Dornbusch, Rudiger, and Sebastian Edwards. 1991. "The macroeconomics of populism." In Dornbusch and Edwards (eds.) The Macroeconomics of Populism in Latin America, pp. 713.

Durante, Ruben, Putterman, Louis, and van der Weele, Joel. 2014. "Preferences for Redistribution and Perception of Fairness: An Experimental Study." Journal of the European Economic Association, Volume 12, Issue 4, August 1, 2014, Pages 1059-1086.

Edwards, Sebastian. 2019. "On Latin American Populism, and Its Echoes around the World." Journal of Economic Perspectives, Vol. 33, No. 4: 76-99.

Eichengreen, Barry. 2018. The Populist Temptation: Economic Grievance and Political Reaction in the Modern Era. Ox ford University Press.

Engerman, Stanley L., and Sokoloff, Kenneth. 2002. "Factor Endowments, Inequality, and Paths of Development Among New World Economics.” No. w9259. National Bureau of Economic Research.

Esping-Andersen, Gosta. 1989. "The three political economies of the welfare state." Canadian Review of Sociology. Vol. 26, Issue 1: 10-36.

Eurobarometer. 2011. Europeans and the Crisis. Special Eurobarometer Report 75.2, European Parliament, 2011.

Eurogroup. 2020. "Understanding the political economy of reforms: Evidence from the EU" European Commission, Technical note for the Eurogroup (September).

Fankhauser, Sam, Caterina Gennaioli and Murray Collins. 2015. "The political economy of passing climate change legislation: Evidence from a survey." Global Environmental Change. Volume 35: 52-61 
Fernandez, Raquel, and Rodrik, Dani. 1991. "Resistance to Reform: Status Quo Bias in the Presence of Individual Specific Uncertainty." American Economic Review. Vol 81(5): 114655.

Finseeras, Henning. 2007. "Voter Turnout, Income Inequality, and Redistribution.” Paper prepared for presentation at the ECPR conference in Pisa, September 2007.

Florini, Ann, and Sunil Sharma. 2020. "Reckoning with Systemic Hazards." Finance and Development. Vol 57, Number 2 (June).

Francese, Maura, and Prady, Delphine. 2018. "Universal Basic Income: Debate and Impact Assessment.” IMF Working Paper 18/273.

Fong, Christina M., Bowles, Samuel, and Gintis, Herbert. 2003. "Strong Reciprocity and the Welfare State." In Mercier-Ythier, Jean and Kolm, Serge (eds.) Handbook on the Economics of Giving, Reciprocity, and Altruism (2004) Part II.

Fujiwara, Thomas. 2015. "Voting technology, political responsiveness, and infant health: Evidence from Brazil.” Econometrica. Vol. 83, No.2 (March), 423-464.

Furceri, Davide, Loungani, Prakash, and Ostry, Jonathan D. 2020. "How Pandemics Leave the Poor Even Farther Behind.” https://blogs.imf.org/2020/05/11/how-pandemics-leave-thepoor-even-farther-behind/

Gennaioli, Nicola, and Guido Tabellini. 2019 "Identity, Beliefs and Political conflict" https://voxeu.org/article/identity-beliefs-and-political-conflict

Gilens, Martin. 2009. "Preference Gaps and Inequality in Representation." PS: Political Science and Politics 42(2): 335-341.

Gilens, Martin, and Benjamin I. Page. 2014. "Testing theories of American politics: Elites, interest groups, and average citizens." Perspectives on Politics 12, no. 3: 564-581.

Giuliano, Paola, and Antonio Spilimbergo. 2014. "Growing up in a recession: Beliefs and the macroeconomy." No. w15321. National Bureau of Research.

Glaeser, Edward L., Giacomo AM Ponzetto, and Jesse M. Shapiro. 2005. "Strategic Extremism: Why Republicans and Democrats divide on religious values." The Quarterly Journal of Economics 120, no. 4: 1283-1330.

Gruber, Jon, and Simon Johnson. 2019. Jump-Starting America. Policy summary. https://www.jump-startingamerica.com/policy-summary 
Guiso, Luigi, Herrera, Helios, Morelli, Massimo and Sonno, Tommaso. 2017. "Populism: Demand and Supply". CEPR Discussion Paper DP1 1871.

Haller, Max, Eder, Anja, and Stolz, Erwin. 2016. "Ethnic Stratification and Patterns of Income Inequality Around the World: A Cross-National Comparison of 123 Countries, Based on a New Index of Historic Ethnic Exploitation". Social Indicators Research, vol. 128: 1047-1084.

Hacker, Jacob. 2012. "The Institutional Foundations of Middle-Class Democracy" cited in https://www.theguardian.com/commentisfree/2012/sep/12/ed-miliband-predistribution.

Hills, John, Paulus, Alari, Sutherland, Holly and Tasseva, Iva. 2014. “A lost decade?

Decomposing the effect of 2001-11 tax-benefit policy changes on the income distribution in EU countries". ImPRovE Discussion Paper No. 14/03, June 2014. http://improve$\underline{\text { research.eu/ }}$

Inglehart, Ronald, and Pippa Norris. 2016. "Trump, Brexit, and the Rise of Populism: Economic Have-Nots and Cultural Backlash.” HKS Working Paper No. RWP16-026.

International Monetary Fund. 2011. Regional Economic Outlook: the Middle East and Central Asia, World Economic and Financial Surveys (Washington). .2013a."Who let the Gini out?" Finance and Development (December). .2013b. "Taxing Times" Fiscal Monitor(October). .2014. "Fiscal Policy and Income Inequality". Policy Paper (January). .2017a. "Tacking Inequality". Chapter 1, Fiscal Monitor (October). .2018. "Age of Insecurity: Rethinking the Social Contract". Finance and Development (December). .2019a. "A Strategy for IMF Engagement on Social Spending,"

Policy Paper No. 19/016. .2019b. "Reallocating Public Spending to Reduce Income Inequality: Can it Work? Working Paper. 
(October).

.2019c. "How to Mitigate Climate Change". Fiscal Monitor

.2020. "Box 1.2 Inclusiveness in Emerging and Developing

Economies and the Impact of Covid-19”. World Economic Outlook(October).

Iversen, Torben, and David Soskice. 2006. "Electoral Institutions and the Politics of Coalitions: Why Some Democracies Redistribute More Than Others." American Political Science Review. Vol 100 (2): 165-81.

Johnson, Simon. 2019a. “The Populist Paradox.” Project Syndicate. May, 31

2019b. "Angry Voters are easier to distract."

https:/www.businesstimes.com.sg/opinion/angry-voters-are-easier-to-distract.

Jones, Charles I. 2019. Taxing Top Incomes in a World of Ideas. No. w25725. National

Bureau of Economic Research.

Kaltwasser, Cristóbal Rovira. 2014. “The Responses of Populism to Dahl's Democratic Dilemmas." Political Studies 62 (3): 470-87.

Karadja, Mounir, Mollerstrom, Johanna, Richer, Seim, David. 2017. "Richer (and Holier) Than Thou? The Effect of Relative Income Improvements on Demand for Redistribution." Review of Economics and Statistics, Vol. 99, Issue 2, May 2017, p.201-212.

Kasara, Kimuli, and Pavithra Suryanarayan. 2014 "When Do the Rich Vote Less Than the Poor and Why? Explaining Turnout Inequality across the World". American Journal of Political Science. Vol 59 (3): 613-27.

Kaufman Robert and Barbara Stallings. 1991. "The political economy of Latin American Populism." In Dornbusch and Edwards. The Macroeconomics of Populism in Latin America.

Kenworthy, Lane, and Leslie McCall. 2007. "Inequality, public opinion, and redistribution." Socio-Economic Review 6, no. 1:35-68.

Korpi, Walter, and Joakim Palme. 1998. "The Paradox of Redistribution and Strategies for Equality: Welfare State Institutions, Inequality, and Poverty in Western countries." American Sociological Review, Vol. 63/5, pp. 661-687.

Kuttner, Robert. 2018. Can Democracy Survive Global Capitalism. W. W. Norton \& Company. 
Kuziemko, Ilyana, Norton, Michael I., Saez, Emmanuel, Stantcheva, Stefanie. 2013. "How Elastic Are Preferences for Redistribution? Evidence from Randomized Survey Experiments." No. w18865. National Bureau of Economic Research.

Kuznets, Simon. 1955. "Economic Growth and Income Inequality." The American Economic Review, Vol. 45, No. 1: 1-28.

Kyle, Jordan, and Gultchin, Limor. 2018a. Populists in Power Around the World. Tony Blair Institute for Global Change. http://institute.global/insight/renewing-centre/populists-poweraround-world.

Kyle, Jordan, and Mounk, Yascha. 2018b. The Populist Harm to Democracy: An Empirical Research. Tony Blair Institute for Global Change. http://institute.global/insight/renewingcentre/populist-harm-democracy.

Leibbrandt, Murray, Ingrid Woolard, Arden Finn, and Jonathan Argent. 2010. "Trends in South African income distribution and poverty since the fall of apartheid." OECD Social, Employment and Migration papers, No. 101.

Lindert, Peter H., 2004, Growing Public: Social Spending and Economic Growth since the Eighteenth Century, Cambridge: Cambridge University.

Lindert, Peter H., 2017. "The rise and future of Progressive Redistribution." Commitment to Equity (CEQ) Working Paper Series 73, Tulane University, Department of Economics.Lustig, Nora. 2017. "Fiscal Policy, Income Redistribution, and Poverty Reduction in Low- and Middle-Income Countries.” Tulane University Working Paper 1701.

Mahler, Vincent; Jesuit, David K., and Piotr Paradowski. 2015. "Electoral Turnout and State Redistribution: A Cross-National Study of Fourteen Developed Countries. Political Research Quarterly, Vol. 67(2): 361-373.

Margalit, Yotam. 2013. "Explaining social policy preferences: Evidence from the Great Recession." American Political Science Review 107, no. 1: 80-103.

Martén, Linna. 2019. "Demand for Redistribution: Individuals' Responses to Economic Setbacks.” The Scandinavian Journal of Economics 121, no. 1:225-242.

Mazzucato, Mariana, and Skidelsky, Robert. 2020. “Toward a new fiscal constitution.” Project Syndicate". July 10, 2020.

McCarthy, Nolan, and Jonas Pontusson. 2011. The Political Economy of Inequality and Redistribution. Chapter 26 in The Oxford Handbook of Inequality. 
McChrystal, Gen. Stanley, Tantum Collings, David Silverman, and Chris Fussell. 2015.

Team of Teams: New Rules of Engagement for a Complex World. New York:

Portfolio/Penguin.

McKinsey Global Institute. 2017. "Six Global Megatrends Testing the Resilience of Europe's Inclusive Growth Model"

Meltzer, Allan H., and Scott F. Richard. 1981. "A rational theory of the size of government." Journal of Political Economy 89, no. 5: 914-927.

Milanovic, Branko. 1998. "Income, inequality, and poverty during the transition from planned to the market economy." World Bank regional and sectoral studies. World Bank.

from democracy."

.2017."The higher the inequality, the more likely we are to move away

https://www.theguardian.com/inequality/2017/may/02/higher-inequality-move-away-from-

democracy-branko-milanovic-big-data

Mollerström, Johanna. 2016. "10. Ethnic fractionalization and the demand for redistribution." Nordic Economic Policy.

Morgan, Jana, and Nathan Kelly. 2013. "Market Inequality and Redistribution in Latin America and the Caribbean." The Journal of Politics. Vol 75(3): 672-85.

Mudde, Cas. 2004. “The Populist Zeitgeist”. Vol. 39, Issue 4: 541-563

Mukand, Sharun W. and Rodrik, Dani. 2019. "The Political Economy of Liberal Democracy." http://j.mp/2oSx0v3.

OECD. 2010. Making Reforms Happen: Lessons from OECD Countries (Paris).

Ostry, Jonathan David, Berg, Andrew, and Tsangarides, Charalambos G. 2014.

"Redistribution, inequality, and growth." International Monetary Fund Staff Discussion Note SDN 14/02.

Ostry, Jonathan David, Loungani Prakash, and Andrew Berg. 2019. Confronting Inequality: How Societies Can Choose Inclusive Growth. Columbia University Press.

Persson, Torsten, and Guido Tabellini. 1999. "The size and scope of government:: Comparative politics with rational politicians." European Economic Review. 43 (4- 6):699735. 
Persson, Torsten, and Guido Tabellini. 2000. Political Economics: Explaining Economic Policy. Cambridge: MIT Press.

. 2003. The Economic Effects of Constitutions: What

do the Data Say? Cambridge: MIT Press

Picketty, Thomas. 2018. "Brahmin Left vs. Merchant Right: Rising Inequality and the Changing Structure of Political Conflict. Evidence from France, Britain and the US, 19482017)" WID. World Working Paper Series 2018/7, World Inequality Lab.

Piven, Frances F., and Cloward, Richard. 1993. Regulating the Poor: The functions of public welfare.

Przeworski, Adam. 2015. "Economic Inequality, Political Inequality, and Redistribution." Draft. Department of Politics. New York University.

Rajan, Raghuram. 2019. The Third Pillar: How Markets and the State Leave the Community Behind. Penguin Press.

. 2020. “Which Post-Pandemic Government?” Project Syndicate. May 22,

2020 ,

Ritter, Michael, and Solt, Frederick. 2019. "Economic Inequality and Campaign Participation.” Social Science Quarterly 100(3): 678-688.

Robinson, James A. 2009. "Good Crises? Implications for Developing Countries". https://scholar.harvard.edu/jrobinson/publications/good-crises-implications-developing$\underline{\text { countries }}$

Rodrik, Dani. 2019. Concluding Remarks at the Peterson Institute for International Economies' conference on “Combating Inequality: Rethinking Policies to Reduce Inequality in Advanced Economies": 17-18 October.

https://www.piie.com/system/files/documents/2019-10-18-s6-rodrik-close-ppt.pdf

Rodrik, Dani, and Sabel, Charles. 2019. "Building a Good Jobs Economy."

https://drodrik.scholar.harvard.edu/publications/building-good-jobs-economy

Roland, Gérard. 2002. “The Political Economy of Transition.” Journal of Economic

Perspectives. Vol. 16, no.: 29-50.

Rosenthal, Howard. 2004. "Politics, Public Policies, and Inequality: A Look Back at the Twentieth Century” in Neckerman Kathryn (Ed.) Social Inequality. 
Roth, Christopher, and Wohlfart, Johannes. 2018. "Experienced Inequality and Preferences for Redistribution." Journal of Public Economics, vol. 167, pp. 251-262.

Sandbu, Martin. 2020. The economics of belonging. Princeton University Press.

Stankova, Olga. 2019. "Frontiers of Economic Policy Communications.” International Monetary Fund Departmental Paper 19/08.

Sumner, Andy, Ortiz-Juarez, Eduardo, Hoy, Chris. 2020. "Precarity and the pandemic: COVID-19 and poverty incidence, intensity, and severity in developing countries". WIDER Working Paper.

Tabellini, Guido. 2019. "Changing Dimensions of Political Conflicts and the Rise of Populism," Fifth Annual Richard Goode Lecture, International Monetary Fund.

United Nations, Department of Economic and Social Affairs. 2020a. World Social Report 2020. Inequality in a Rapidly Changing World.

https://www.un.org/development/desa/dspd/world-social-report/2020-2.html

United Nations, Department of Economic and Social Affairs. 2020b. "COVID-19 Recovery Measures Could Prevent Widening Inequalities due to the Pandemic".

https://www.un.org/fr/desa/covid-19-recovery-measures-could-prevent-widening-

$\underline{\text { inequalities-due-pandemic }}$

Weyland, Kurt. 2001. "Clarifying a Contested Concept. Populism in the Study of Latin American Politics", Comparative Politics, 34: 1.

Wolf, Martin. 2020. "Democracy will fail if we don't think as citizens." Financial Times Series, July 6, 2020.

World Bank. 2000. "The Effectiveness of the World Bank's Poverty Reduction Strategy: An Evaluation." Washington DC.

.2015. "The Poverty Focus of Country Programs: Lessons from World Bank Experience". Washington DC.

Washington DC.

. 2017. "World Development Report 2017. Governance and the Law”. 